Article

\title{
Agglutinated Foraminiferal Acmes and Their Role in the Biostratigraphy of the Campanian-Eocene Outer Carpathians
}

\author{
Anna Waśkowska (D)
}

check for

updates

Citation: Waśkowska, A.

Agglutinated Foraminiferal Acmes

and Their Role in the Biostratigraphy

of the Campanian-Eocene Outer

Carpathians. Geosciences 2021, 11, 367.

https: / / doi.org/10.3390/

geosciences 11090367

Academic Editors: Lucilla Capotondi,

Maria Rose Petrizzo, Angela

Cloke-Hayes and Jesus

Martinez-Frias

Received: 19 July 2021

Accepted: 26 August 2021

Published: 31 August 2021

Publisher's Note: MDPI stays neutral with regard to jurisdictional claims in published maps and institutional affiliations.

Copyright: (C) 2021 by the author. Licensee MDPI, Basel, Switzerland. This article is an open access article distributed under the terms and conditions of the Creative Commons Attribution (CC BY) license (https:/ / creativecommons.org/licenses/by/ $4.0 /)$.
Department of General Geology and Geotourism, Faculty of Geology, Geophysics and Environmental Protection, AGH University of Sciences and Technology, al. Mickiewicza 30, 30-122 Kraków, Poland; waskowsk@agh.edu.pl; Tel.: +48-12-617-36-10

\begin{abstract}
The biostratigraphy of the Outer Carpathians is based mainly on the ranges of agglutinated foraminifera. Species acmes provide the opportunity to enhance and support the existing biozonations. Assemblages of agglutinated foraminifera from the Campanian to Eocene of various tectonic-structural units were analyzed in terms of their qualitative and quantitative occurrence. In this stratigraphic interval, 19 species display significantly increased abundance within a relatively short interval: Caudammina gigantea (Geroch) (upper Santonian-lowermost Maastrichtian), Caudammina ovulum (Grzybowski) (Campanian-Danian), Placentammina placenta (Grzybowski)Saccammina grzybowskii (Schubert) (upper Campanian-Danian), Caudammina excelsa (Dylazżanka) (lowermost Maastrichtian-Danian), Caudammina ovuloides (Grzybowski) (Danian-Selandian), Hormosina velascoensis (Cushman) (upper Danian-Selandian), Praesphaerammina gerochi (Hanzlíková) (Thanetian), Glomospira charoides (Jones et Parker)-Glomospira gordialis (Jones et Parker) (uppermost Thanetian-lowermost Ypresian), Trochammina spp. (upper Thanetian-lower Ypresian), Reticulophragmium amplectens (Grzybowski) (Lutetian-Bartonian), Reophax duplex (Grzybowski)-Reophax "pilulifer" Brady group of taxa (Lutetian-Priabonian), Haplophragmoides walteri (Grzybowski)-Haplophragmoides nauticus Kender, Kaminski et Jones (Lutetian-Bartonian), Spiroplectammina spectabilis (Grzybowski) (Lutetian-Priabonian), "Ammodiscus" latus Grzybowski (Bartonian-Priabonian), Praesphaerammina subgaleata (Vašíček) (Lutetian-Bartonian). The biostratigraphic position and quantitative data of species with increased abundance are presented.
\end{abstract}

Keywords: agglutinated foraminifera; biostratigraphy; late Cretaceous-Paleogene; acme zones; Outer Carpathians

\section{Introduction}

Dating of the Cretaceous and Lower Paleogene deep-water Outer Carpathian deposits, dominated by turbidites, is generally based on the biostratigraphy. Due to some limitations, other methods are used sporadically. A commonly used microfossil group is the agglutinated foraminifera. Other groups, i.e., planktonic foraminifera, dinocysts, calcareous nannoplankton, and calpionellids, have limited applications, because their preservation depends on the nature of the paleoenvironment, i.e., oxygen deficiency or paleodepth relative to the CCD level. The agglutinated foraminifera in deep-water deposits have a universal application because they occur consistently, settled on the turbiditic sea floor, and lived in-situ. They produced durable tests, elements predominately from quartz silt and sand, and inhabited deep-water environments, both above and below the CCD. The agglutinated foraminifera had good fossilization potential and were successfully preserved in the fossil record. This group is among the most widespread microfossils. They are well preserved and occur abundantly within muddy- and clay-intervals of turbidities. For this reason, biozonations based on the agglutinated foraminifera are of great importance and are widely used ([1] and references therein). The interval zones or partial range zones after the first published biozonation [2] are distinguished most often. Taking into account acme 
zones, the Glomospira div. sp. acme zone is the most widely distinguished as the most characteristic, with the index taxon showing a dramatic increase in number. However, generally acmes zones have limited use. The exception is the Outer Carpathian biozonation [3] where part of the zones is in the rank of acmes. The acmes are associated with the index species and apart from the Glomospira div. sp. acme zone, the total range of other index taxa characterize a relatively narrow stratigraphic range.

The qualitative data, next to the quantitative, indicate that within the deep-water Outer Carpathian deposits foraminiferal assemblages can be found with significantly increased numbers of a single species or group of species. These numerous occurrences are observed in units representing various sedimentary areas of the Outer Carpathian basins and are coeval. The current study specifies the foraminiferal species abundances, both short-ranging and long-ranging species, presents their percentage ratio, and considers their potential use in the biostratigraphy of the deep-water Carpathian deposits.

\section{Study Area}

The study was conducted in the Western Outer Carpathians mainly on the Polish territory. The Outer Carpathians consist of stratigraphic units originated from the northwestern part of the Tethys Ocean, along its outer margin. They consist mainly of turbidites deposited from the Jurassic to the Miocene within several sedimentary basins separated by ridges (Figure 1). The number and position of these basins changed through time. Generally, the Magura and Silesian domains can be distinguished within the Western Outer Carpathian Tethys ([4-7] and references therein). The more southern was the Magura Domain and it was related to the Alpine Tethys [4]. The Magura Basin and the Foremagura Basin (including the Dukla Basin in the Cretaceous and earliest) were connected. The Magura Domain was bordered by the Silesian Ridge with the Silesian Domain located to the north (Figure 1). The Silesian Domain comprised the most external part of the Tethys and contains the Silesian and Skole basins, the Paleogene stage of the Foremagura group of basins as well as the areas of the Subsilesian Ridge (Subsilesian Sedimentary Area). It was connected with the Neotethys [5]. The Outer Carpathians are the northern part of the Carpathian Orogenic Belt. They have a nappe structure and are overthrusted onto the European Plate ([4-8] and references therein) (Figure 2). Particular nappes more or less refer to the original individual sedimentary basins, thus the Magura Nappe contains the deposits of the Magura Basin, the Silesian Nappe contains the deposits of the Silesian Basin, the Skole Nappe consists of the deposits of the Skole Basin, the Foremagura group of nappes contains deposits of the Dukla Basin and other Foremagura basins, and the Subsilesian Nappe holds the deposits of the Subsilesian Sedimentary Area related to the uplifted Subsilesian Ridge and its surroundings. Micropaleontological studies were carried out mainly in the Magura, Silesian, and Subsilesian nappes, subordinately in other Outer Carpathian nappes (Figure 2). 


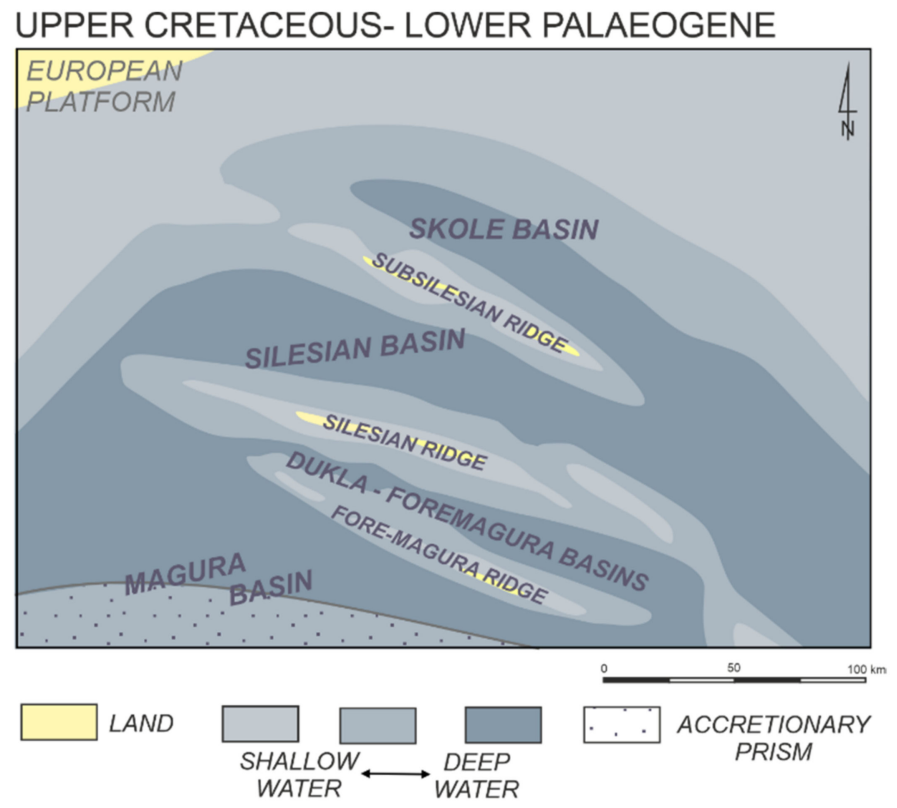

Figure 1. Paleogeographical sketch map of the Outer Carpathian basins in late Cretaceous-lower Paleogene times (after [5], modified).

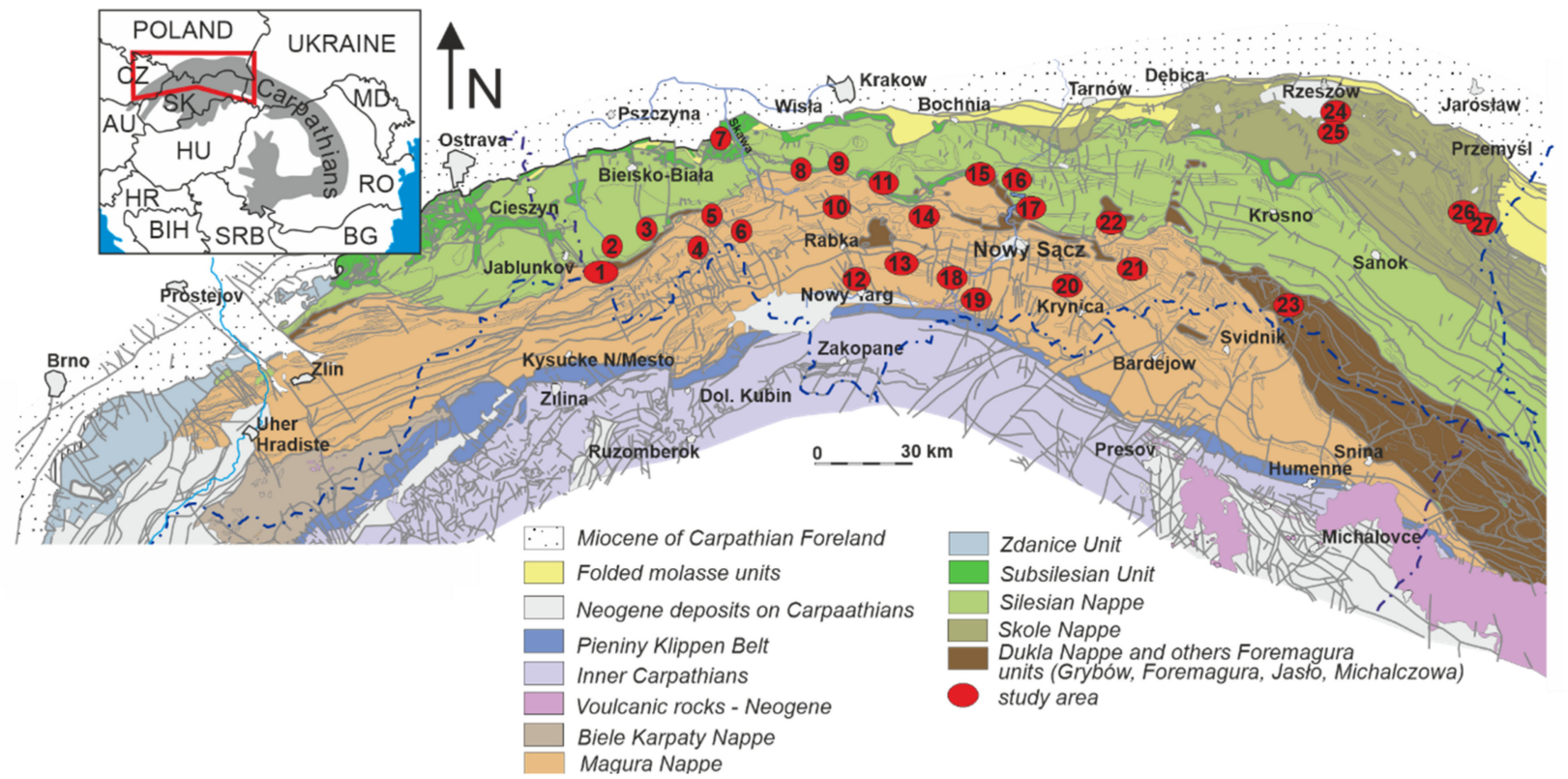

Figure 2. Location of the studied sections on the general geological map of the Western Carpathians (map on the basis of [9]—modified). Study areas: 1: Jaworzynka, Pod Mutnym, Szare, Wawrzeczów Groń sections; 2: Olza, Janoska, Kamesznica, Jasnowice, Istebna sections; 3: Leśna, Leśnianka sections; 4: Mutne section; 5: Sucha Beskidzka, Skawce, Śleszowice, Rzyczki sections; 6: Mosorny, Składy sections; 7: Bachowice Las, Szydłowiec, Gorzeń sections; 8: Harbutowice, Harbutowice/Jasienica, Gościbia, Ubionka sections; 9: Zamczysko, Stróża sections; 10: Osielec, Tokarnia sections; 11: Foszczówka, Glichów, Czerwin, Wiśniowa sections; 12: Nowy Targ section; 13: Lubomierz, Farony, Jeżowe sections; 14 : Szczyrzyc, Krzyworzeka, Stradomka, Krzesławice, Krzeszów sections; 15: Stare Rybie, Nowe Rybie, Pluskawka, Żegocina sections; 16: Melsztyn section; 17: Lipie, Jezioro Rożnowskie sections; 18: Zarzecze section; 19: Ścigocki section; 20: Klimkówka, Nowica sections; 21: Bodaki section; 22: Gorlice, Szymbark, Ropica, Sękówka sections; 23: Jasiółka section; 24: Zabratówka section; 25: Poręby-Czarnotówki, Błażowa, Straszydle, Zimny Dział sections; 26: Leszczawa section; and 27: Makowa section. 


\section{Materials and Methods}

The studied agglutinated foraminifera have been obtained from shales (mudstones, muddy claystones, and claystones). Samples were taken from: the upper part of a turbidite sequences, mostly from ungraded turbidite mudstone deposited from suspension or from shally complexes. The shales were diverse within one lithostratigraphic unit. Mudstones gray or greenish in color prevailed over red-colored clayey mudstones and claystones. In general, red colored shales are considered to be deposits formed in well-oxygenated environments, while dark mudstones, which are usually characterized by elevated levels of TOC, are found sediments of oxygen-limited conditions. Studies were carried out in the most continuous segments (parts) of sections, then they were combined into composite sections. Location of the sections is indicated in Figure 2. Several to 40 samples were taken from each single segment of section. The starting weight of the crude rock was $500 \mathrm{~g}$; only a small part of the samples had a weight closer to $300 \mathrm{~g}$. The foraminifera were obtained by: maceration of the sampled sediment in heated and cooled $\mathrm{Na}_{2} \mathrm{SO}_{4}$ solution, and washing over a $63-\mu \mathrm{m}$ mesh sieve. The fossils were picked from the clastic residue. To obtain quantitative data, all foraminifera were picked up from the whole sample, or from a split if they were particularly numerous. They were identified and counted. The numerical data were compiled only from foraminiferal assemblages with at least a hundred specimens, usually more than 300 specimens. Data from 400 samples were considered in this study; the samples were collected from the Magura, Foremagura, Dukla, Silesian, Subsilesian, and Skole nappes (Figures 2 and S1). Quantitative data (\% share in the benthic assemblage, excluding tubular foraminifera, Figure S1) allow to select species that proportions in given time intervals increase significantly (acme) and this phenomenon is repeatable within the structural unit/units of the Outer Carpathians. A minimal percentage abundance (lower limit of acme) has been established separately for individual species and varied from 3 to $20 \%$. In fossil material, tubular foraminifera are preserved as numerous fragments of tubes and often constitute the dominant component of the assemblage. A single living tubular foraminifera produces several dozen to a few hundred fragments, which essentially distort the perception of the original image of a foraminiferal assemblage. In fact the tubular forms constitute a marginal component considering the abundance of the individual living organisms [10]. Therefore, for the purpose of this work, the tubular forms like Bathysiphon spp., Nothia spp., Rhabdammina spp., Rhizammina spp., and Psammosiphonella spp. are not included in the calculations. As a result, the general calculation error is minimal and does not distort the presented statistical data.

The foraminiferal tests were analysed under a Nikon VL 100POL binocular microscope at the Department of General Geology and Geotourism of Faculty of Geology, Geophysics and Environment Protection AGH. Photographic documentation was done using a Nikon Digital SIGHT DS-Fi1 camera, and a FEI QUANTA 200 FEG scanning microscope at the Scanning Microscopy Laboratory. The age of the samples was determined biostratigraphically using agglutinated foraminifera (zonation after [3]), or planktonic foraminifera if present. Of secondary importance was superposition within the section in relation to the dated samples, and assignment to lithostratigraphic units.

Paleontological materials are housed in the author's collection at the AGH University of Science and Technology and in Micropress Europe Foundation (al. Mickiewicza 30, 30-059 Kraków, room 225a and 234).

\section{Results}

In the turbiditic deposits of the Outer Carpathians, mostly long-ranging agglutinated foraminifera are found and the variability in diversity of foraminiferal assemblages is rather very low. The most numerous specimens belong to the primitive creeping Nothia species or erect tubular Rhabdammina or Psammosiphonella species. Other common and numerous forms are Recurvoides spp., Trochamminoides and Paratrochamminoides spp., and-in the Paleogene deposits-Ammosphaeroidina pseudopauciloculata (Mjatliuk), which constitute the basic taxa. Other species, mostly cosmopolitan, are common but constitute a marginal 
component of the samples amounting usually maximally $1 \%$ of the assemblage. In particular time intervals, the relative proportions of some marginal species significantly increase and they display acmes noted in the regional scale. Based on quantitative data, 19 species whose numbers periodically increase were selected, and they are indicated in Figure 3. The growth ratio varies for the particular species (Figures 3 and S1). The descriptions of acmes including the threshold values and average abundances of acme taxa, their occurrence, age assignment, and remarks of the literature review are presented below.

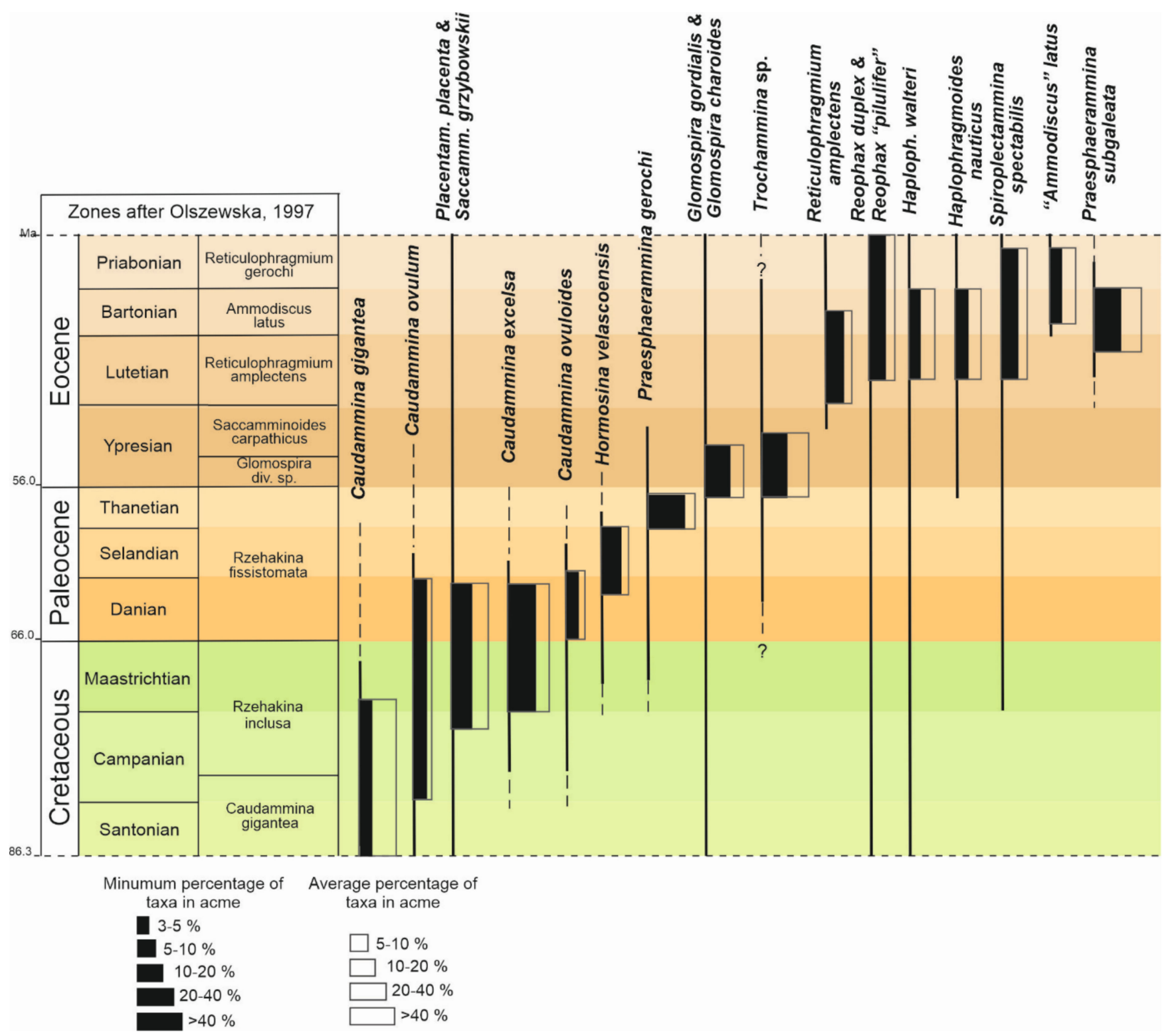

Figure 3. Biostratigraphical scheme of upper Cretaceous and lower Paleogene with distribution of taxa acmes in the Outer Carpathians (time scale after [11]).

\subsection{Caudammina gigantea (Geroch) Acme \\ 4.1.1. Definition}

An increased amount of Caudammina gigantea (Geroch) specimens (Figure 4) ranges $5 \%$ or more per assemblage. Together with numerous $C$. gigantea, an increased number of Placentammina placenta (Grzybowski) of up to over a dozen, sporadically several dozen percent in the upper part is observed. The Maastrichtian drop in C. gigantea specimen number coincides with the increase in taxonomical diversity and appearance of new 
taxa in the Outer Carpathian assemblages, such as Glomospira diffundens Cushman et Renz, Spiroplectammina spectabilis (Grzybowski), Remesella varians (Glaessner), Annectina grzybowskii (Jurkiewicz), and Hormosina velascoensis (Cushman).

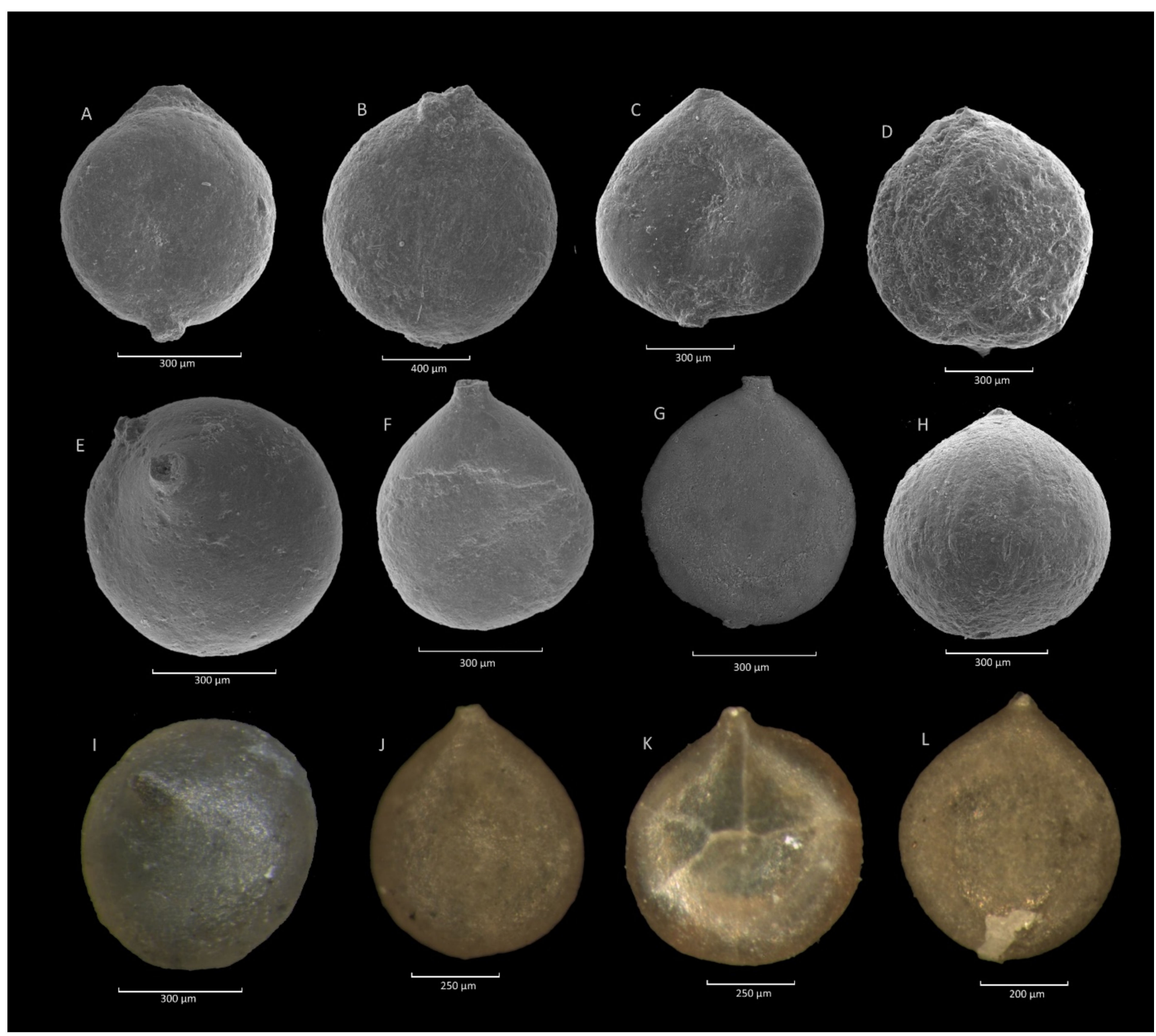

Figure 4. Caudammina gigantea Geroch. (A-C,E,F,K): Zimny Dział section; (D): Mutne section; (G,L): Ropica section; $(\mathbf{H}, \mathbf{I})$ : Lubomierz section; (J): Jaworzynka section.

\subsubsection{Occurrence and Age Assignment}

Uppermost Santonian-lowermost Maastrichtian (Figures 3, 5 and S1), commonly in the Magura and Silesian domains. 

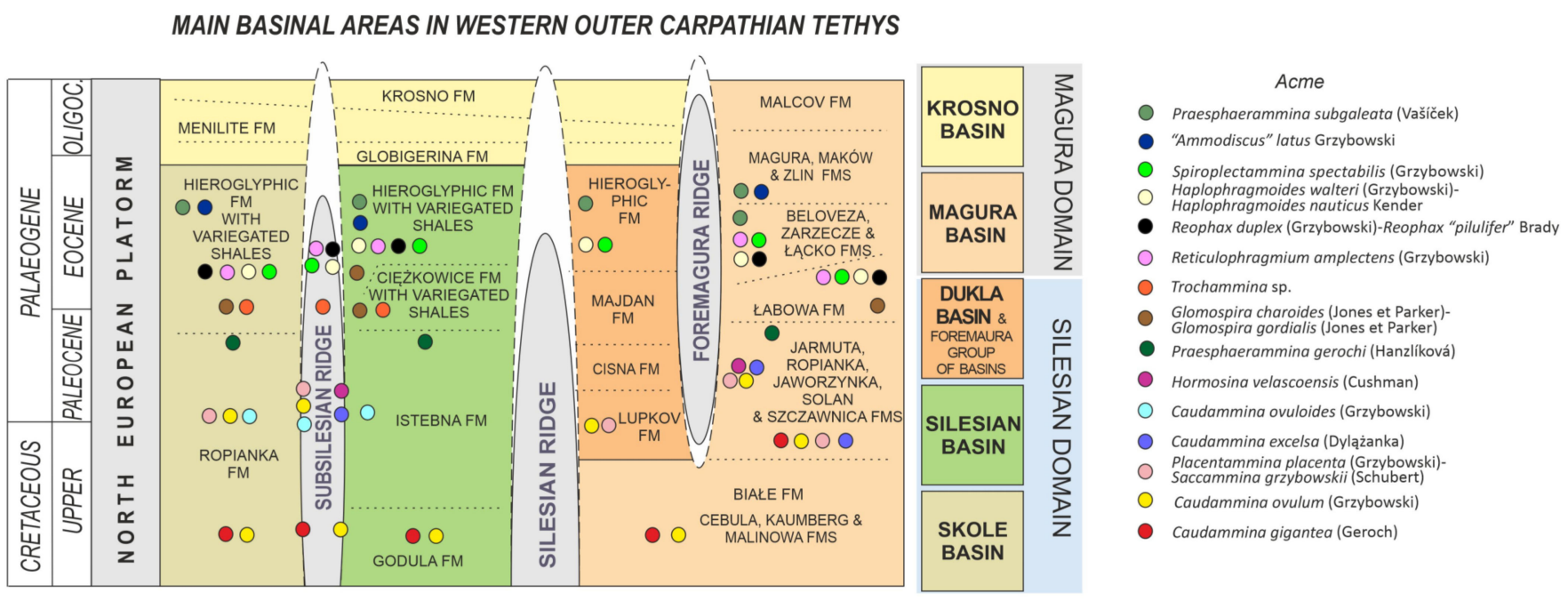

Figure 5. Main basinal lithostratigraphic units with acmes in the Outer Western Carpathians (on the basis of [4]).

\subsubsection{Remarks}

C. gigantea is known in the Outer Carpathians from the upper Cretaceous and the lower Paleocene. Its first appearance is indicated from the lower Santonian and its last occurrence is assigned to the middle Paleocene ([2,3,12-14] and references therein). C. gigantea occurs only in fragments, as single chambers. A large variation in quantities is observed. In low-diversity assemblages with several co-occurring species, its share is usually over $25 \%$, but in some assemblages it dominates. In higher-diversified assemblages its amount is about $5-25 \%$. The maximum proportion amounting to $63 \%$ has been observed in the Silesian Nappe.

The growth in the number of $C$. gigantea begins in the Campanian and lasts until the lowermost Maastrichtian, ending within the Gansserina gansseri planktonic foraminiferal zone [15]. In the upper part of the acme, the species Rzehakina inclusa (Grzybowski) co-occurs.

Assemblages with abundant $C$. gigantea were widely used in the Outer Carpathian stratigraphy. They were commonly reported from the Magura Nappe [12,15-27], quoted from the Subsilesian and Silesian nappes [15,28,29]; from the Skole Nappe [30,31] and from the Dukla Nappe [32]. They were observed in the Pieniny Klippen Belt [33]. The authors of [34] indicated the universal biostratigraphical use of $C$. gigantea abundant assemblages in the Outer Carpathians, which was the basis for establishing the Caudammina gigantea acme zone of late Santonian-early Maastrichtian age. The Caudammina gigantea zone is used commonly for North Atlantic stratigraphy; it ranges from middle-upper Campanian to Maastrichtian ([35-38] and references therein). Similar use was introduced in the Contessa Highway section near Gubbio Italy [39].

Numerous C. gigantea occurs in different types of muddy and marly shales, the largest proportion being in the red clayey shales. The species is more frequent in the Magura Domain than in the Silesian. C. gigantea is characteristic for deep water, mainly bathyal, carbonate-poor environments with low terrigenous detrital input [36].

\subsection{Caudammina ovulum (Grzybowski) Acme}

\subsubsection{Definition}

The growth of C. ovulum (Figure 6) is up to 3\% or more specimens in the assemblage. Abundant $C$. ovulum occurs within two types of assemblages. From the Campanian to lowermost Maastrichtian within low-diversified assemblages it co-occurs with C. gigantea. Moreover, it is present in higher-diversified Maastrichtian-Paleocene assemblages. In some Maastrichtian-Paleocene assemblages, it co-occurs with other relatively abundant Caudammina spp. such as Caudammina excelsa (Dylażanka) and/or Caudammina ovuloides (Grzybowski), as well as with an increased number, about a few percent, of Saccammina spp. 


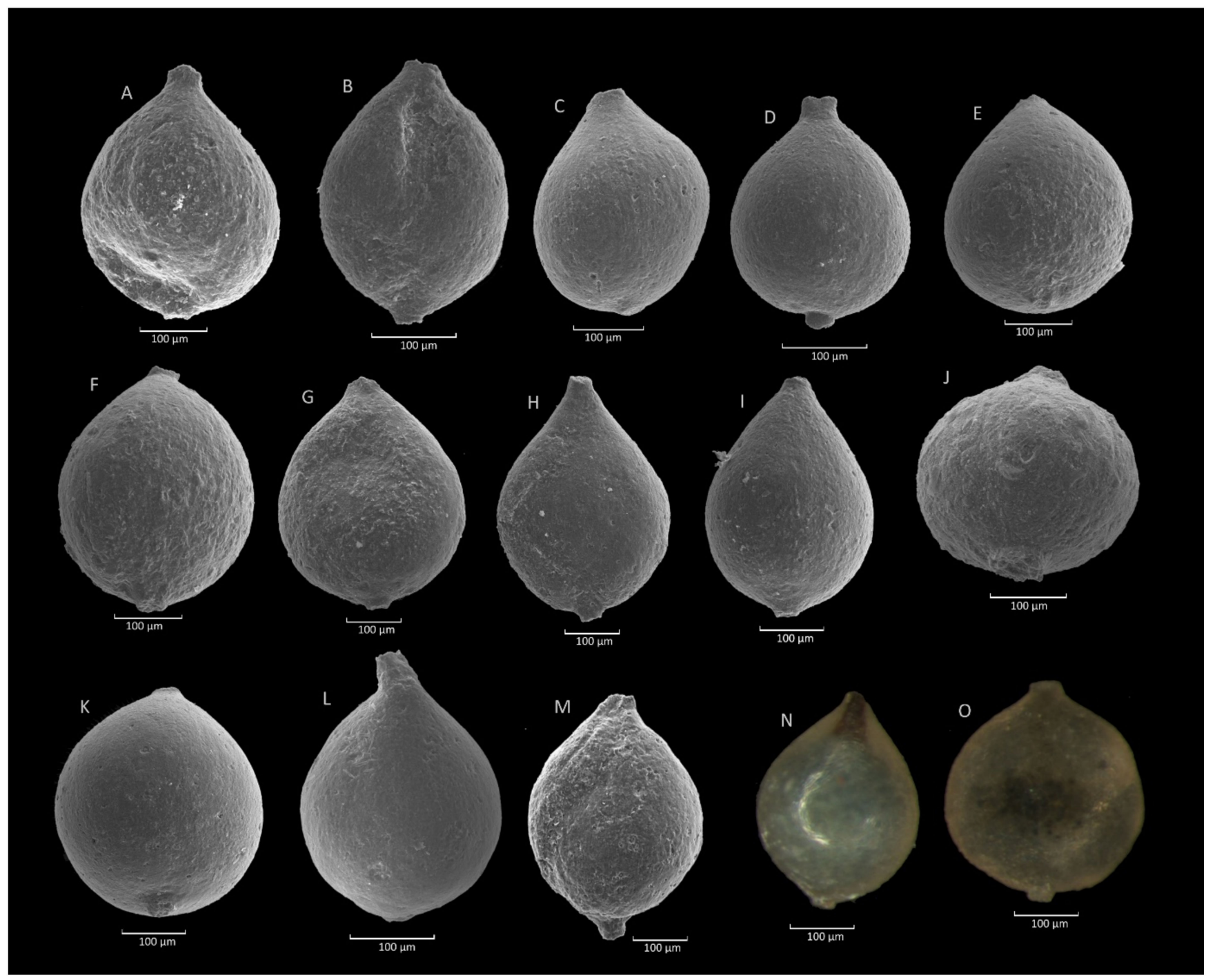

Figure 6. Caudammina ovulum (Grzybowski). (A): Szydłowiec section; (B,D,I,K): Mutne section; (C,H): Rzyczki section; (E-G): Gorzeń section; (J,L): Zimny Dział section; (M): Gościbia section; (M-O): Jaworzynka section.

\subsubsection{Occurrence and Age Assignment}

Campanian (upper Senonian?)-Danian (Figures 3, 5 and S1), Magura, and Silesian domains.

\subsubsection{Remarks}

In the Outer Carpathians C. ovulum is known from the lower Cretaceous up to the lower Eocene [28], and is abundant from the Santonian to the lower Paleocene. In the Carpathian deposits, C. ovulum occurs only as single chambers, uniserial specimens are not known. The maximum proportion reaching 39\% was observed in the Paleocene deposits of the Magura Nappe. The increase in C. ovulum is typical of the upper part of the Caudammina gigantea zone, it occurs irregularly within the Rzehakina inclusa zone, and it is common in the lower part of the Rzehakina fissistomata zone.

C. ovulum-rich assemblages from the Santonian of the Silesian Nappe were reported by [20]; its higher relative abundance with numerous C. gigantea was described by $[21,25,26]$.

Abundant C. ovulum was reported in the lower Paleocene of the Skole and Magura nappes [40], from the Paleocene of the Subsilesian Nappe [18] and Silesian Nappe [28,41], and from the upper Senonian and Paleocene in the Magura Nappe [42-44]. The relative 
abundance of Caudammina was the basis for distinguishing the Caudammina association in the Danian of the Subsilesian Nappe [14]. In this type of assemblages the total quantity of Caudammina and H. velascoensis reached up to $45 \%$ of the assemblage. An increased number of C. ovulum was reported from the Paleocene of the Eastern Outer Carpathians [45,46], from the Boreal realm from the uppermost Cretaceous [38] and in the Paleocene of the Tasman Sea.

\subsection{Placentammina placenta (Grzybowski)-Saccammina grzybowskii (Schubert) Acme}

\subsubsection{Definition}

The relative abundance of P. placenta and/or Saccammina grzybowskii (Schubert) (Figures 7 and 8 ) ranges $10 \%$ or more in the foraminiferal assemblage. Frequent Saccammina-Placentammina spp. occurs in lower- or higher-diversified assemblages having different taxonomical structure. Usually the second most abundant co-occurring taxon is $H$. excelsa, in a quantity of a few to a dozen percent (occasionally more) or $A$. pseudopauciloculata in the quantity of a dozen percent. Characteristic of the acme is the occurrence of large-sized specimens of P. placenta, large-sized specimens of Glomospira glomerata (Grzybowski), Glomospira ex. gr. irregularis (Grzybowski), and particularly numerous Trochamminoides-Paratrochamminoides spp. in part of the assemblages.

\subsubsection{Occurrence and Age Assignment}

Upper Campanian-Danian (Figures 3, 5 and S1), commonly in the Magura and Silesian domains.

\subsubsection{Remarks}

Both species belong to widespread long-ranging cosmopolitan species ([1] and references therein). In the Outer Carpathians, they occur commonly in Cretaceous and Paleogene deposits, usually as a permanent accessory component. An abundance of $P$. placenta and/or S. grzybowskii is observed from the upper (uppermost?) Campanian to the lower Paleocene. The total domination of P. placenta with S. grzybowskii is rare. The standard amount of the acme varies between $20 \%$ and $35 \%$. The maximum number, reaching over $60 \%$, was observed in Upper Cretaceous deposits of the Foremagura Nappe.

P. placenta dominated assemblages were described from the Moravian Paleocene [47]; assemblages with abundance of $P$. placenta were mentioned in many papers referring to the Outer Carpathian Paleocene deposits [16,40-42,44,48-51], as well as the upper Cretaceous and Paleocene deposits, both in the Magura and Silesian domains as well $[15,28,52,53]$. High amounts of P. placenta were observed in the uppermost Paleocene of the Eastern Carpathians [46].

Next to the Campanian-Paleocene acme, an increased number of P. placenta with S. grzybowskii is also observed in Lower Eocene assemblages with very low taxonomical diversity. Such assemblages are not common.

The P. placenta-S. grzybowskii acme usually occurs in grey mudstones with increased TOC values (0.4-0.5\% TOC) [44]. It developed in low energy environments with a significant delivery of organic matter. S. grzybowskii represents different morphotypes; the species is in need of revision. 


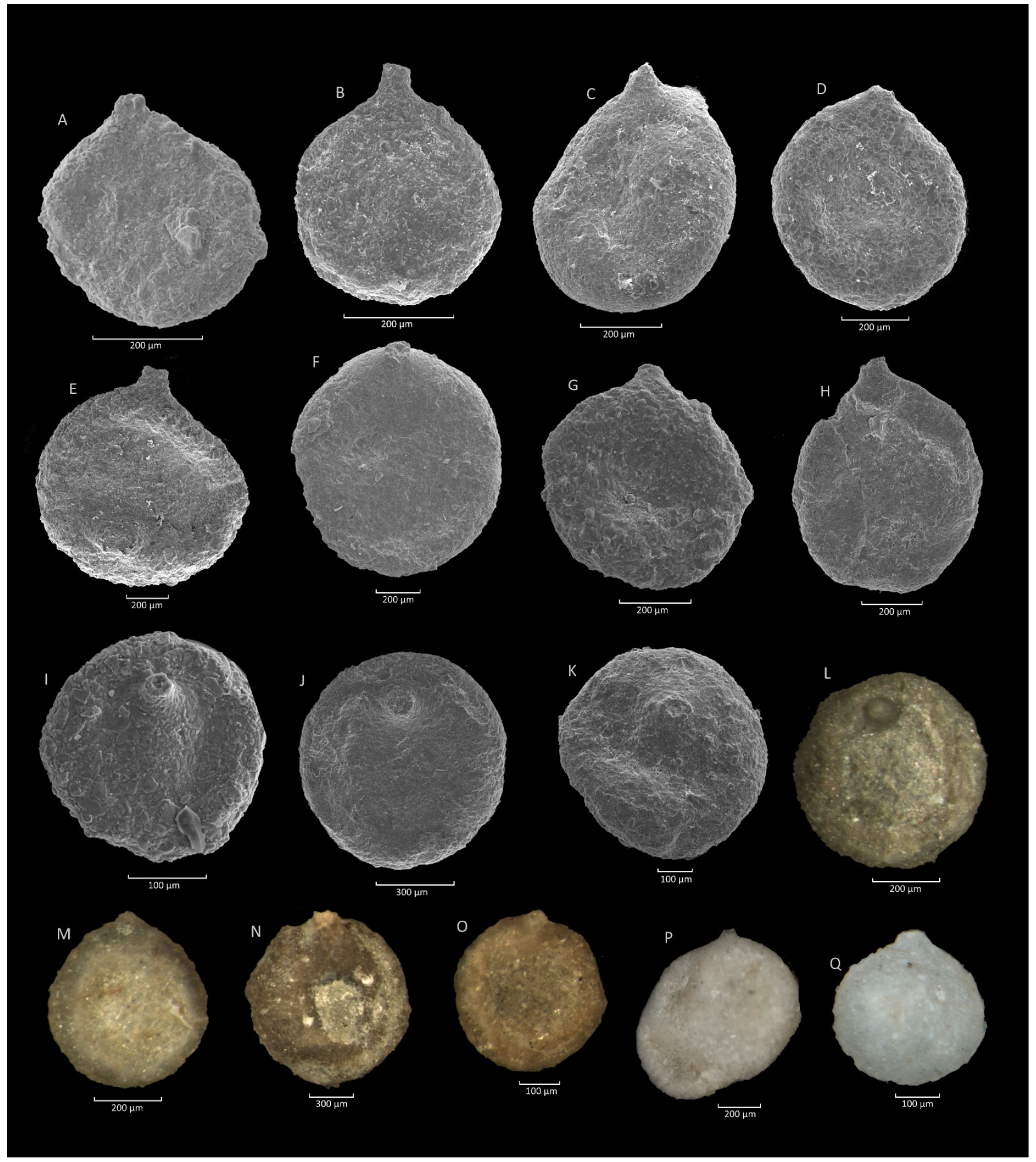

Figure 7. Placentammina placenta (Grzybowski). (A): Zimny Dział section; (B): Mutne section; (C,D): Rzyczki section; (E): Mutne section; (F): Krzesławice section; (G): Gorzeń section; (H): Jaworzynka section; (I): Poręby-Czarnotówki section; (J): Rzyczki section; (K): Mutne section; (L,M): Jaworzynka section; (N,O): Świątkowa section; (P): Gorlice section; (Q): Melsztyn section. 


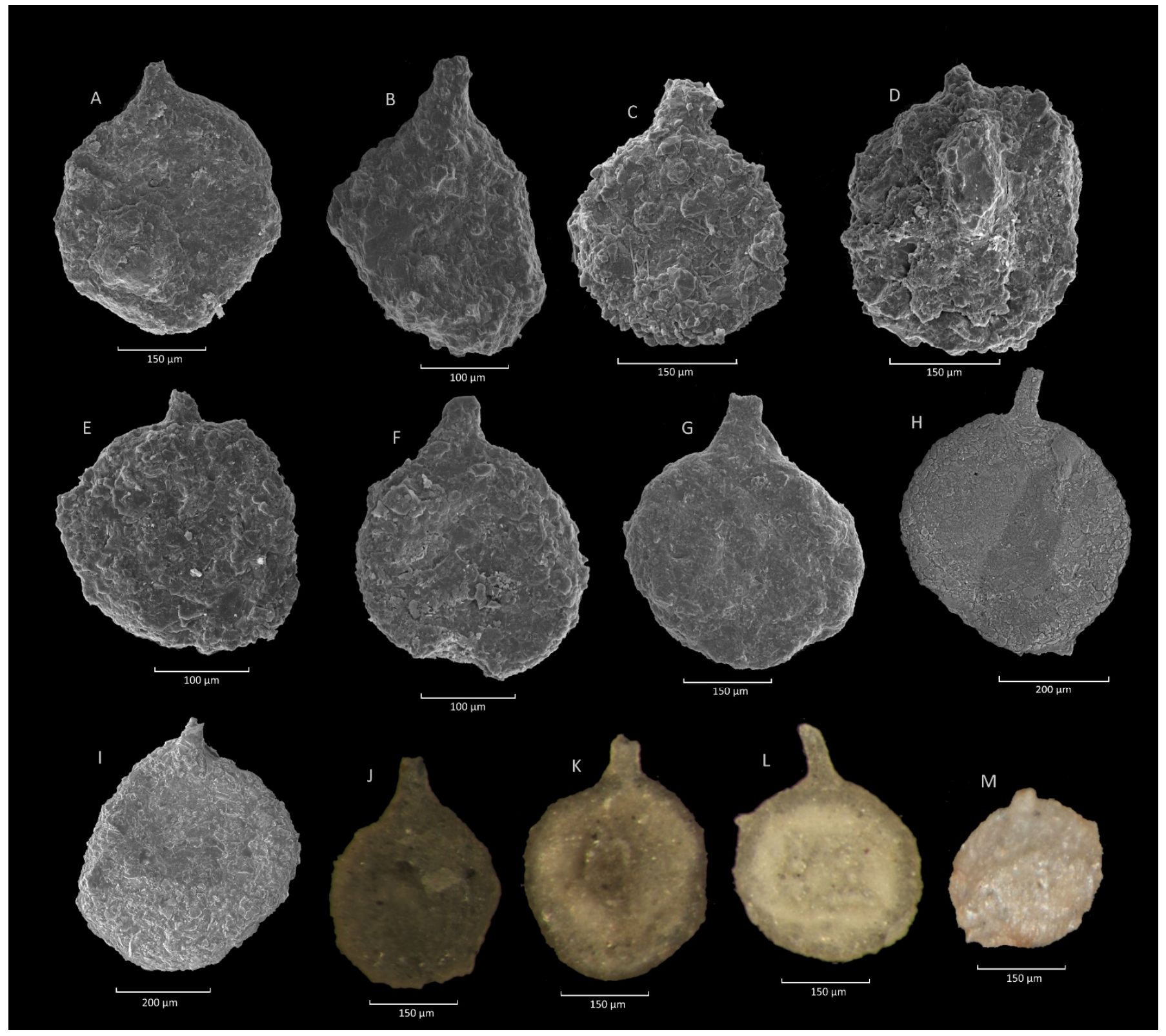

Figure 8. Saccammina grzybowskii (Schubert) type group. (A): Gorzeń section; (B): Jaworzynka section; (C-E): Krzesławice section; (F): Mutne section; (G): Rzyczki section; (H,I): Ropica section; (J): Jaworzynka section; (K,L): Ropica section; (M): Olecka section.

\subsection{Caudammina excelsa (Dylażanka) Acme 4.4.1. Definition}

The relative abundance of $C$. excelsa (Figure 9) specimens in assemblages is at least $3 \%$ or more. In the lower part of the acme, it co-occurs with $R$. inclusa and Cretaceous planktonic foraminifera, whilst in the upper part with Rzehakina fissistomata (Grzybowski). In some assemblages with relatively abundant $C$. excelsa, an increased number, usually a dozen percent of P. placenta and S. grzybowskii can occur, and an increase in the abundance of Paratrochamminoides spp. or/and Recurvoides spp. is also observed. 


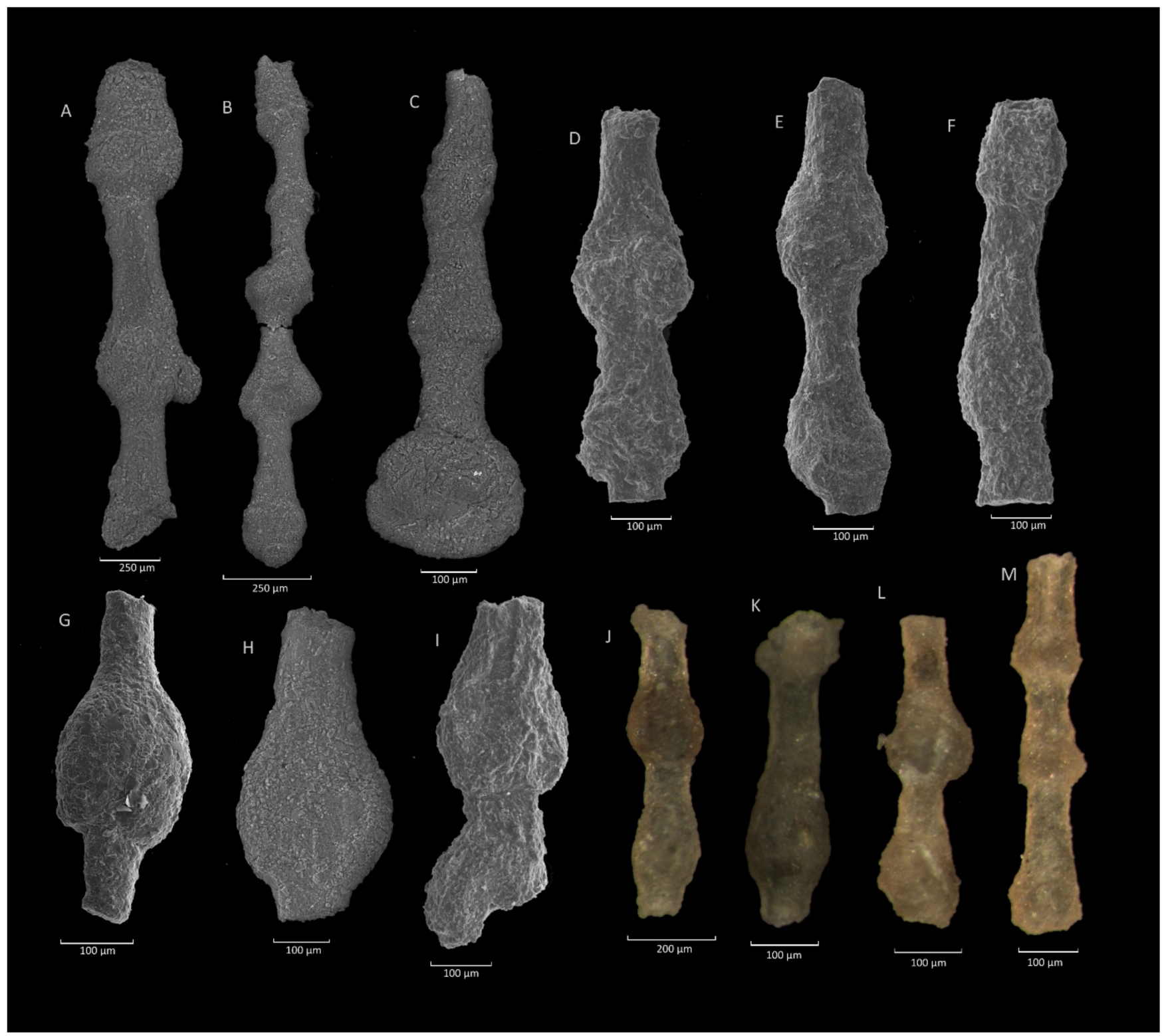

Figure 9. Caudammina excelsa (Dylążanka). (A-C,H,L,M): Ropica section; (D,F): Rzyczki section; (E,I): Mutne section; (G): Stradomka section; (J,K): Jaworzynka section.

\subsubsection{Occurrence and Age Assignment}

Lowermost Maastrichtian-Danian (lower Paleocene) (Figures 3, 5 and S1), Magura, and Silesian domains.

\subsubsection{Remarks}

C. excelsa is noted commonly from Campanian up to Paleocene in the Outer Carpathians, less often from the lower Eocene [1,40,52-54]. C. excelsa in the assemblages occurs usually as one- to four-chamber fragments. Relatively abundant $C$. excelsa is observed from the lowermost Maastrichtian to the lower Paleocene. On average, a relative abundance of $15-30 \%$ is common. A maximum proportion of $63 \%$ was observed in assemblages from the Subsilesian Nappe. It is present in assemblages with a dozen or several dozen species, some assemblages are highly-diversified.

Numerous C. excelsa were commonly observed in the deposits of the Outer Carpathians. Relatively abundant C. excelsa in the Magura Nappe was described: in Upper Creta- 
ceous deposits $[21,22,25,44]$, in the Paleocene deposits by $[27,44,49]$, and in CampanianMaastrichtian and Maastrichtian-lower Paleocene deposits [22,23,43]. It was noticed in the Silesian Nappe [28,55-58] and in other Western Outer Carpathian areas [30,52], significant amounts were the basis for distinguishing the C. excelsa-R. inclusa beds [57]. In the Eastern Outer Carpathians, the relatively abundant occurrence of $C$. excelsa is known from the Paleocene [45,46], as well as from the uppermost Cretaceous of the Boreal realm [38].

Relatively abundant C. excelsa occurs in grey and green mudstones with an increased TOC values (about $0.4-0.6 \%$ ). It is interpreted as related to high siliciclastic input and organic matter flux and low oxygen content ([44,52] and references therein).

\subsection{Caudammina ovuloides (Grzybowski) Acme}

\subsubsection{Definition}

The occurrence of relatively abundant C. ovuloides (Figure 10) specimens is up to $3 \%$ or more in foraminiferal assemblage. Co-occurring abundant Recurvoides spp. and large-sized Paratrochamminoides spp. are common.

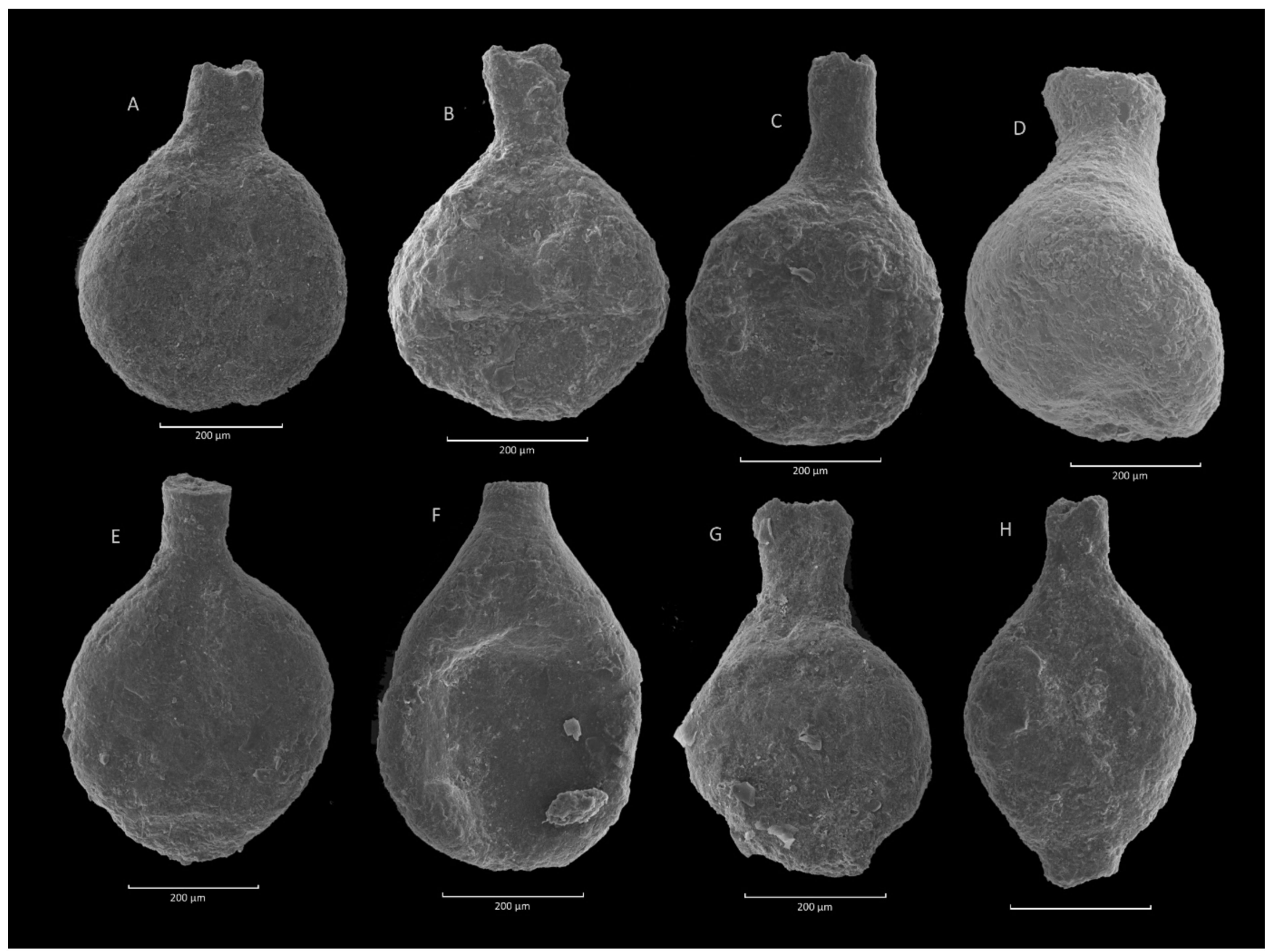

Figure 10. Caudammina ovuloides (Grzybowski). (A-E,G): Zimny Dział section; (F,H): Sucha Beskidzka section.

\subsubsection{Occurrence and Age Assegment}

Danian-lower Selandian (Figures 3, 5 and S1), Silesian Domain.

\subsubsection{Remarks}

Usually the C. ovuloides amount is $3-10 \%$, but a quantity of a dozen percent or more is occasionally observed. The maximum proportion, amounting to 39\%, was observed in 
the Skole Nappe, but this is exceptional. Relatively abundant C. ovuloides is observed in highly-diversified assemblages with a dozen or several dozen species. It occurs usually as one-chamber fragments of a uniserial test.

C. ovuloides is not very often recognized as a separate species; Early workers [18] suggested that there is no argument for distinguishing this morphotype as a separate species. In the Subsilesian Nappe, deposits with relatively abundant C. ovuloides have been reported [14,59-61]. It occurs in the lower part of the Rzehakina fissistomata zone. An increased number of C. ovulum and C. ovuloides was reported from the Paleocene of the Eastern Outer Carpathians [45] as well as from the uppermost Cretaceous of the Boreal realm [38].

C. ovuloides is most frequent in different types of shales, but higher numbers were observed in the grey shales.

\subsection{Hormosina velascoensis (Cushman) Acme} 4.6.1. Definition

The rise in H. velascoensis specimens (Figure 11) is at least up to $3 \%$ of specimens in the assemblage.

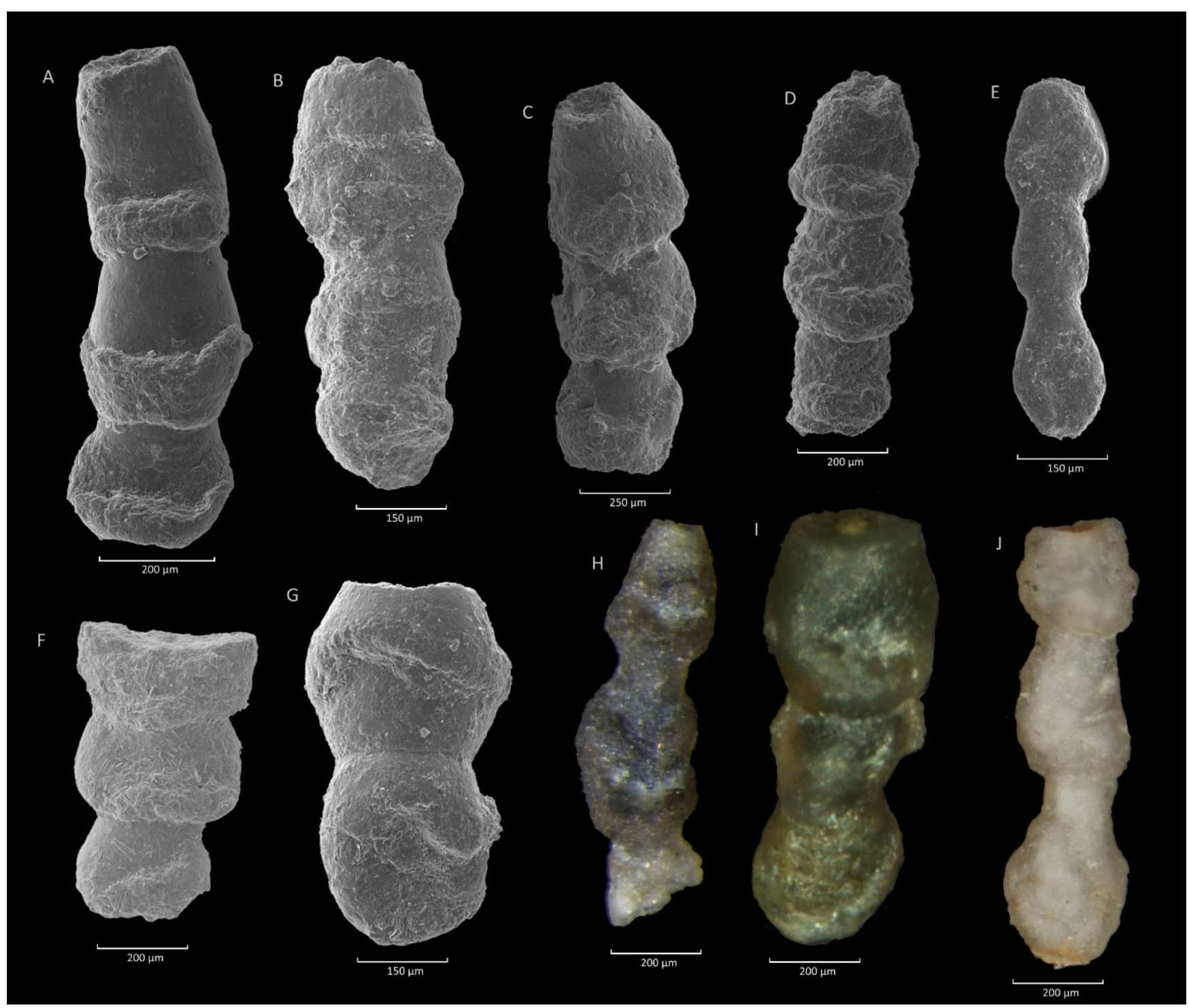

Figure 11. Hormosina velascoensis (Cushman). (A): Stradomka section; (B,E,F): Zimny Dział section; (C): Gorzeń section; (D,G,I): Szydłowiec section; (H): Ropica section; (I,J): Szymbark section. 
Relatively abundant $H$. velascoensis occurs in highly-diversified assemblages and co-occurs with Caudammina spp. and with abundant Recurvoides spp. and large-sized Paratrochamminoides spp.

\subsubsection{Occurrence and Age Assignment}

Upper Danian-Selandian (Figures 3, 5 and S1), Magura, and Silesian domains.

\subsubsection{Remarks}

H. velascoensis is a characteristic species, and is used in the biostratigraphy of the Outer Carpathians as an indicator for the Maastrichtian-lower Paleocene [34,58]. In the Carpathian deposits, $H$. velascoensis tests tend to fragment and usually occur as one- to five-chamber segments. Unusually, its number amounts to $10-20 \%$ of specimens, but the highest relative abundance was observed in the Subsilesian Nappe and reached 32\%.

Relatively abundant $H$. velascoensis was described in Paleocene deposits of the Magura Nappe $[19,40]$ and in the Paleocene of the Subsilesian Nappe [14,18,61,62]. A value of $6.7 \%$ of H. velascoensis was mentioned from the Paleocene of the Eastern Carpathians [46], about a $10 \%$ share was reported from Bulgaria [63].

Relatively abundant $H$. velascoensis usually occurs in the grey and green muddy shales typical for environments with a supply of organic matter, in the red and variegated clay they are rare.

\subsection{Praesphaerammina gerochi (Hanzliková) Acme \\ 4.7.1. Definition}

The abundance of Praesphaerammina gerochi (Hanzlíková) (Figure 12) is a minimum of $5 \%$ of foraminiferal assemblage. Bathysiphon spp. and Recurvoides spp. are the main taxa co-occurring with P. gerochi.

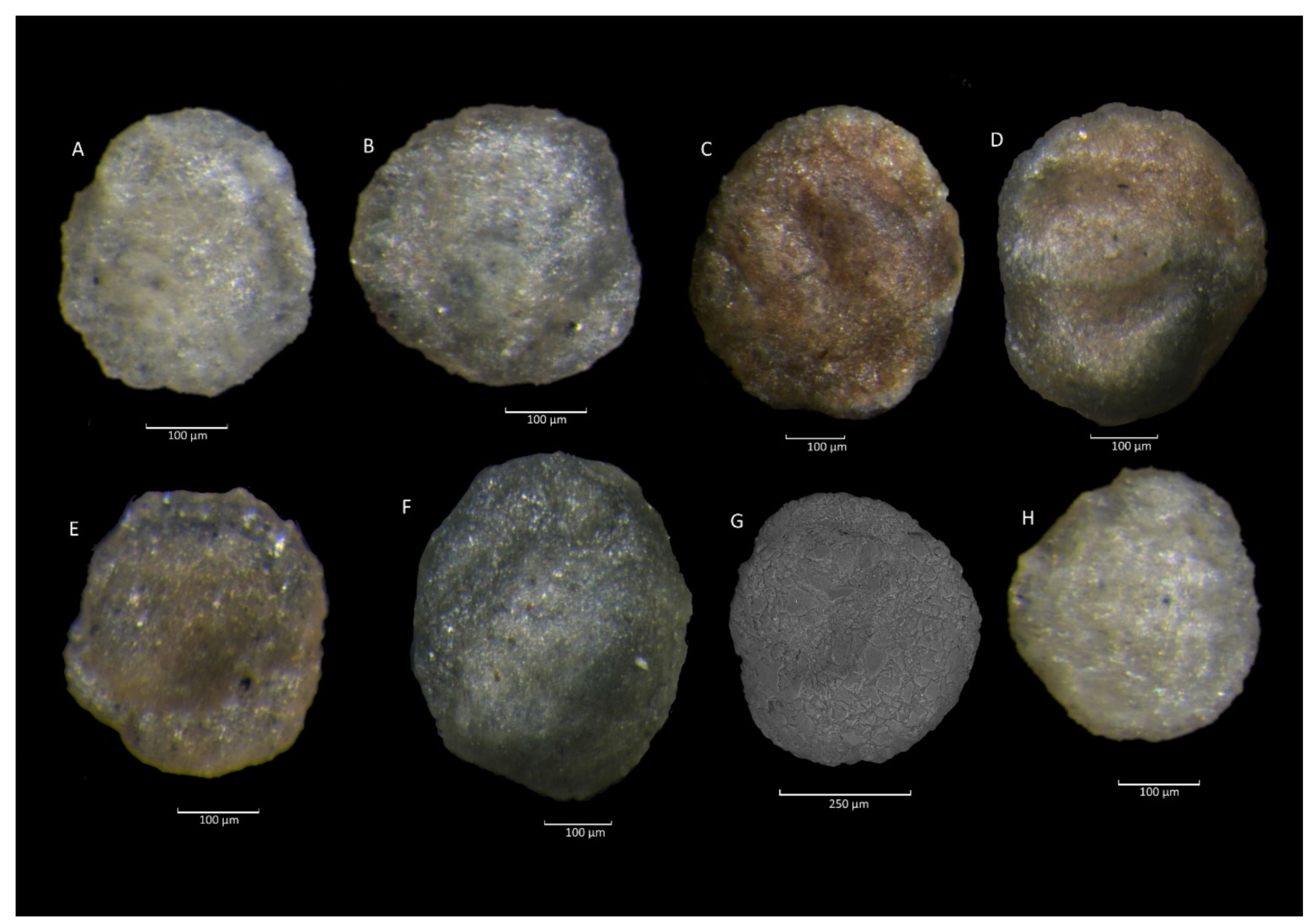

Figure 12. Praesphaerammina gerochi (Hanzlíková). (A,B,E): Kamesznica section; (C,D): Istebna section; (F,H): Błażowa section; (G): Nowica section. 


\subsubsection{Occurrence and Age Assignment}

Thanetian (Figures 3, 5 and S1), commonly in the Silesian Domain, rare in the Magura Domain.

\subsubsection{Remarks}

P. gerochi is known from the upper Cretaceous to the lower Eocene in the Carpathians $[1,40,52,58,64,65]$. A large variation in its quantity is observed. In low-diversified assemblages with several co-occurring species, its proportion is usually $25 \%$ or more, and it is often the dominant taxon. In higher-diversified assemblages its amount is lower. The maximum abundance was mentioned by [40], who described nearly monospecific assemblages from the upper Paleocene shales. Higher-diversified assemblages contain a lower proportion of $P$. gerochi, usually about $20-30 \%$.

P. gerochi was described in the early 1970s [58] as Sphaerammina gerochi Hanzlíková; earlier it was counted together with Praesphaerammina subgaleata (Vašíček). In older literature, the differences between the Paleocene and Eocene specimens of $P$. subgaleata were underlined, for Paleocene forms the cf. designation or "depressa form" was used $[18,28,66,67]$.

The Paleocene Sphaerammina gerochi zone was distinguished in the Silesian Nappe [58]. In the Paleocene "Sphaerammina subgaleata (Vašíček)", abundant or almost monospecific P. gerochi assemblages were reported from the Silesian and Subsilesian nappes [12,28]. Low-diversity P. gerochi-Bathysiphon spp. assemblages were noted from the Subsilesian Nappe $[18,68]$. The authors of [34] reported an increase in P. subgaleata generally in the Outer Carpathian Paleocene. It also occurs in large numbers in western Spitzbergen lower Eocene deposits [1], and in the Paleocene of the Tasman Sea [69].

Numerous $P$. gerochi are present in grey and dark shales. The dominant or totally monospecific assemblages occur within black or dark grey shales with siderite concretions and abundant pyrite. P. gerochi preferred oxygen-poor environments rich in organic matter.

\subsection{Glomospira charoides (Jones et Parker)-Glomospira gordialis (Jones et Parker) Acme} 4.8.1. Definition

The proportion of Glomospira spp. is $20 \%$ or more in the assemblage. Bathysiphon spp., Recurvoides spp., Paratrochamminoides spp. and Trochamminoides spp. are the main co-occurring taxa.

\subsubsection{Occurrence and Age Assignment}

Uppermost Thanetian-lower Ypresian (Figures 3, 5 and S1), common in the Silesian and Magura domains.

Glomospira acme assemblages commonly contain abudant Recurvoides spp. and Thalmannammina spp. in the amount of several dozen percent (as a rule, $20-40 \%$ or more), a dozen percent of Paratrochamminoides spp. and up to a dozen percent of A. pseudopauciloculata. In some assemblages an abundance of Karrerulina spp. is observed.

\subsubsection{Remarks}

The proportion of Glomospira spp. is usually $20-40 \%$ in an assemblage. The dominance of G. charoides with G. gordialis (Figure 13) is not so frequent and it occurs in low-diversity assemblages. The Glomospira spp. dominated assemblages were described as almost monotypic [2], and the highest amount (reaching $90 \%$ of Glomospira) was observed in the Silesian Nappe. 


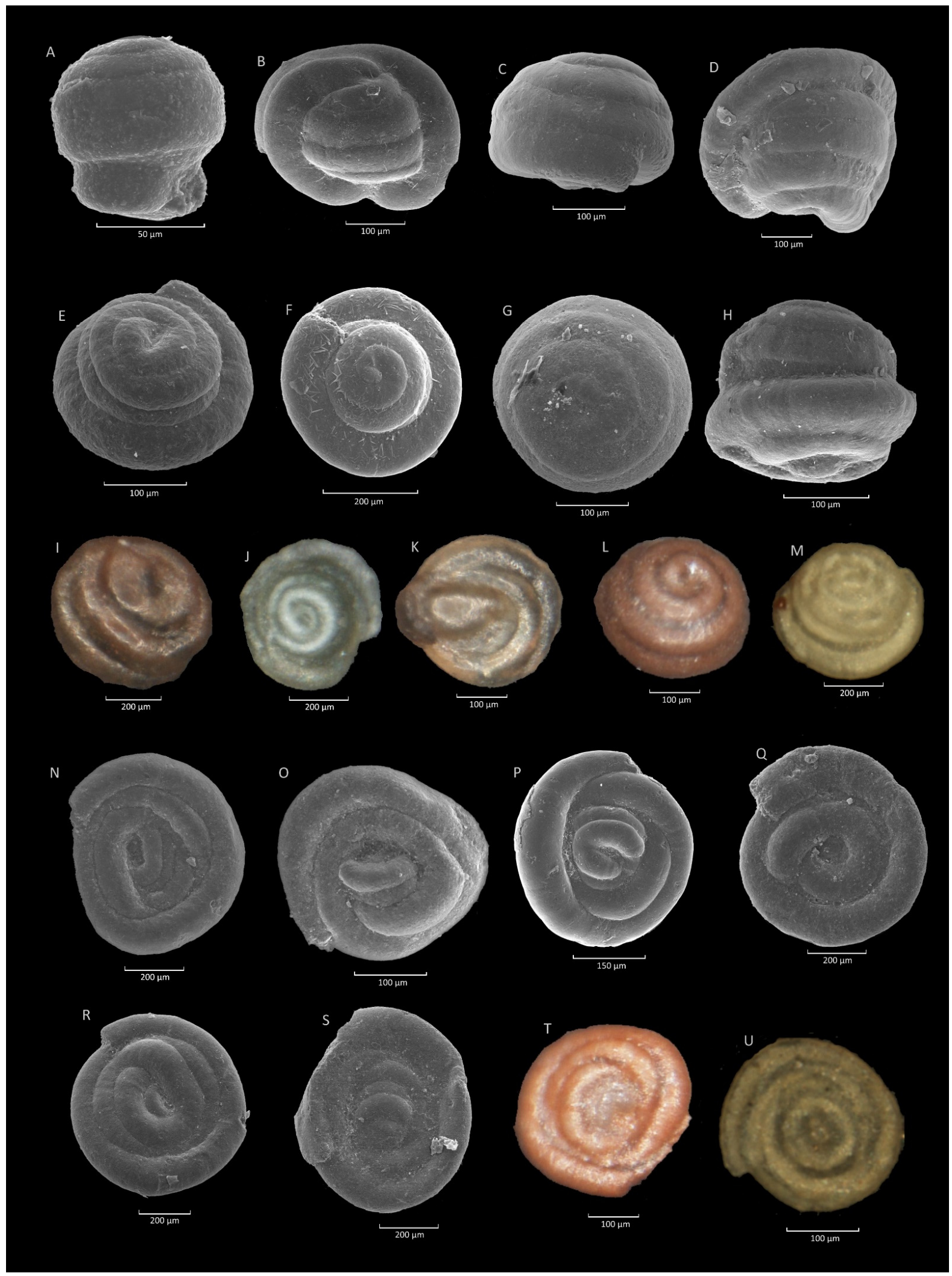

Figure 13. Glomospira charoides (Jones et Parker). (A): Czerwin section; (B): Krzesławice section; (C): Stradomka section; (D): Poręby-Czarnotówki section; (E): Sucha Beskidzka section; (F): Krzesławice section; (G): Mutne section; (H): Olecka section; (I): Gorlice section; (J): Olecka section; (K,L): Zamczysko section; (M): Klimkówka section. Glomospira gordialis (Jones et Parker); (N): Jezioro Rożnowskie section; (O): Lipie section; (P): Krzeszów section; (Q): Sucha Beskidzka section; (R): Rzyczki section; (S): Mutne section; (T): Zamczysko section; (U): Klimkówka section. 
Abundant G. charoides and G. gordialis occur in low-diversified assemblages. The presence of dwarf foraminifera is typical for this assemblages, which is particularly visible among the Glomospira specimens. The individual share of G. charoides and G. gordialis in the acme is variable, usually G. charoides is the most abundant. In majority, the Glomospira acme assemblages are rich in specimens.

A lower Eocene age was assigned by [3] based on planktonic foraminifera (Zone P6b-P7 of [70]).

Glomospira acme assemblages are widely reported from the lower Eocene Outer Carpathian deposits of the Magura Nappe [12,16,17,19,21,23-26,40,53]), from the Subsilesian Nappe $[18,61,71]$, from the Silesian Nappe $[28,40,41]$, from the Dukla Nappe $[30,52,72]$ and from the Skole Nappe [73,74]. It is used in the Outer Carpathian biostratigraphy as an acme zone of earliest Ypresian age [3]. The early Ypresian Glomospira acme is a world-wide phenomenon and it is connected with the Paleocene-Eocene Thermal Maximum and mass extinction of benthic foraminifera in the late Paleocene and early Eocene ([1,75-78] and references therein).

Abundant Glomospira spp. are identified within different types of uppermost Paleocene and lower Eocene mudstones in the Outer Carpathians. It seems that the largest proportion of G. charoides and G. gordialis is found in red shales, reflecting oxygenated conditions with a low supply of clastic material.

\subsection{Trochammina spp. Acme}

4.9.1. Definition

The number of Trochammina spp. amounts to a minimum of $20 \%$. Bathysiphon spp., Recurvoides spp., Paratrochamminoides spp. and Trochamminoides spp. are the main cooccurring taxa. In higher-diversified assemblages a relative abundance of over a dozen percent of G. charoides, and a few percent of Haplophragmoides walteri (Grzybowski) occur.

\subsubsection{Occurrence and Age Assignment \\ Upper Thanetian-lower Ypresian (Figures 3, 5 and S1), Silesian Domain.}

\subsubsection{Remarks}

The acme consists of small-sized Trochammina spp. (Figure 14), that have not been unequivocally assigned to any species. However, it is a group with consistent morphological features referring to a single species, resembling Trochammina globigeriniformis (Parker et Jones). The number of Trochammina spp. usually amounts to $20-50 \%$ and it can be the dominant taxa. In the upper Paleocene deposits of the Silesian Nappe, its maximum share was 55\% [78], while in the lower Eocene deposits it reached 90\%.

The taxonomical diversity of Trochammina acme assemblages is low, e.g., usually over a dozen species. The age of the Trochammina acme was established with reference to rare planktonic and benthic foraminifera $[78,79]$ and it requires further clarification. The assemblages with the Trochammina acme are abundant in specimens, their number is from a few up to 30 specimens per $1 \mathrm{~g}$ of mudstone sample. Locally in the lower Eocene Trochammina acme assemblages replaced the Glomospira acme assemblages.

The authors of [52] mentioned the Recurvoides spp., Trochamminoides spp., Paratrochamminoides spp., and small-sized Trochammina spp. dominated assemblages from the upper Paleocene of the Dukla Nappe. Significant growth of small-sized Trochammina spp. was observed within deposits of the Paleocene-Eocene Thermal Maximum anomaly in Spitzbergen [80].

Assemblages with abundant Trochammina spp. have features of post crisis assemblages. The low taxonomical diversity with high number of a single taxon and the occurrence of dwarf specimens including Trochammina spp. is characteristic. The Trochammina acme assemblages lived in a low energy environment with a continuous and relatively large supply of fine siliciclastic material and a reduced supply of organic matter [79]. They are found in grey muddy shales. 


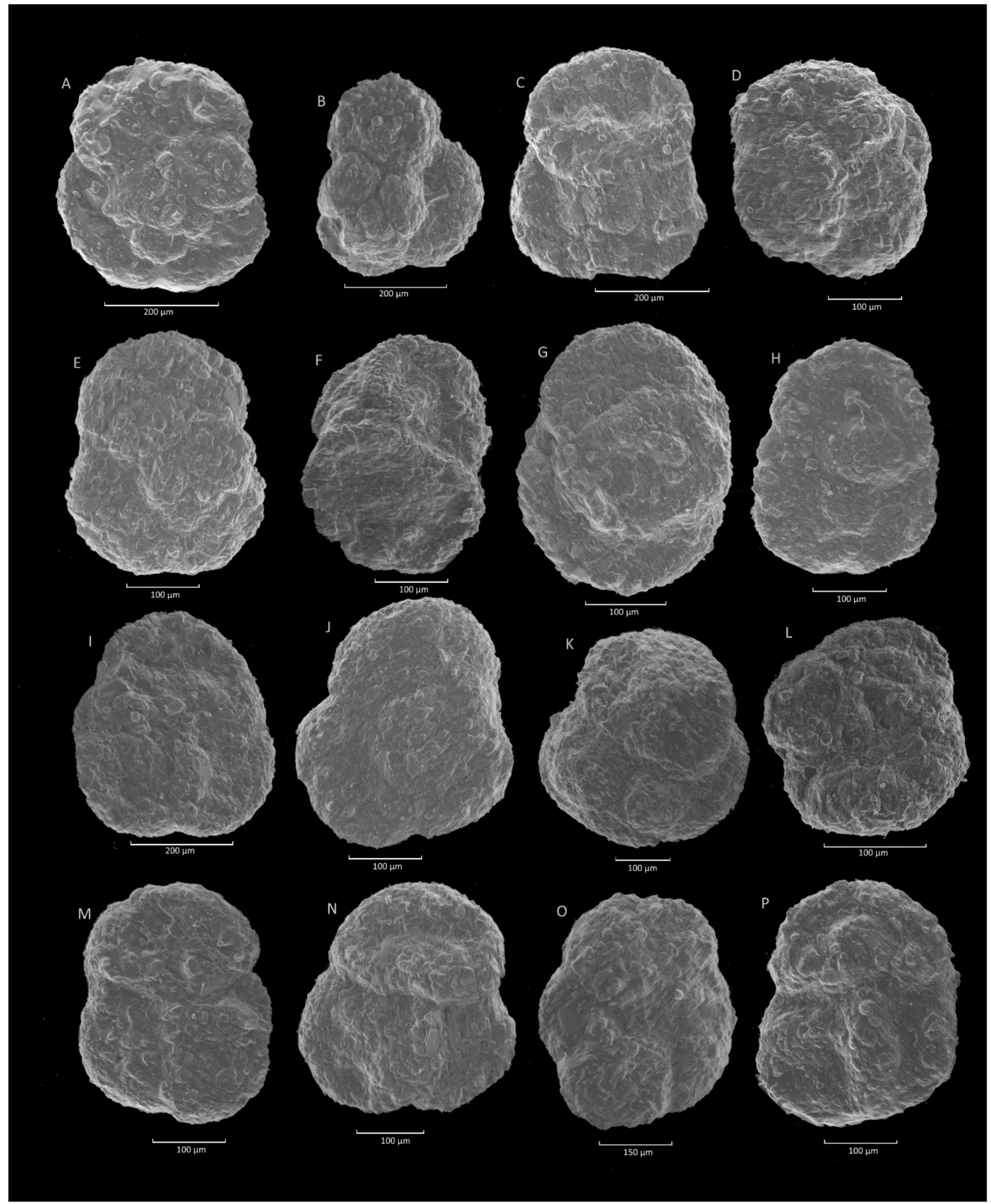

Figure 14. Trochammina sp. (A-C,E): Krzesławice section; (D,F-J,M,O): Janoska section; (K,L,N,P): Stradomka section.

4.10. Reticulophragmium amplectens (Grzybowski) Acme 4.10.1. Definition

The increase in Reticulophragmium amplectens (Grzybowski) (Figure 15) is up to 10\% or more in assemblages. Other numerous taxa are Recurvoides spp. with the share of several dozen percent and Paratrochamminoides spp. in various amounts. In some assemblages Reophax spp. or Karrerulina spp. are also present in amounts of a few percent. 


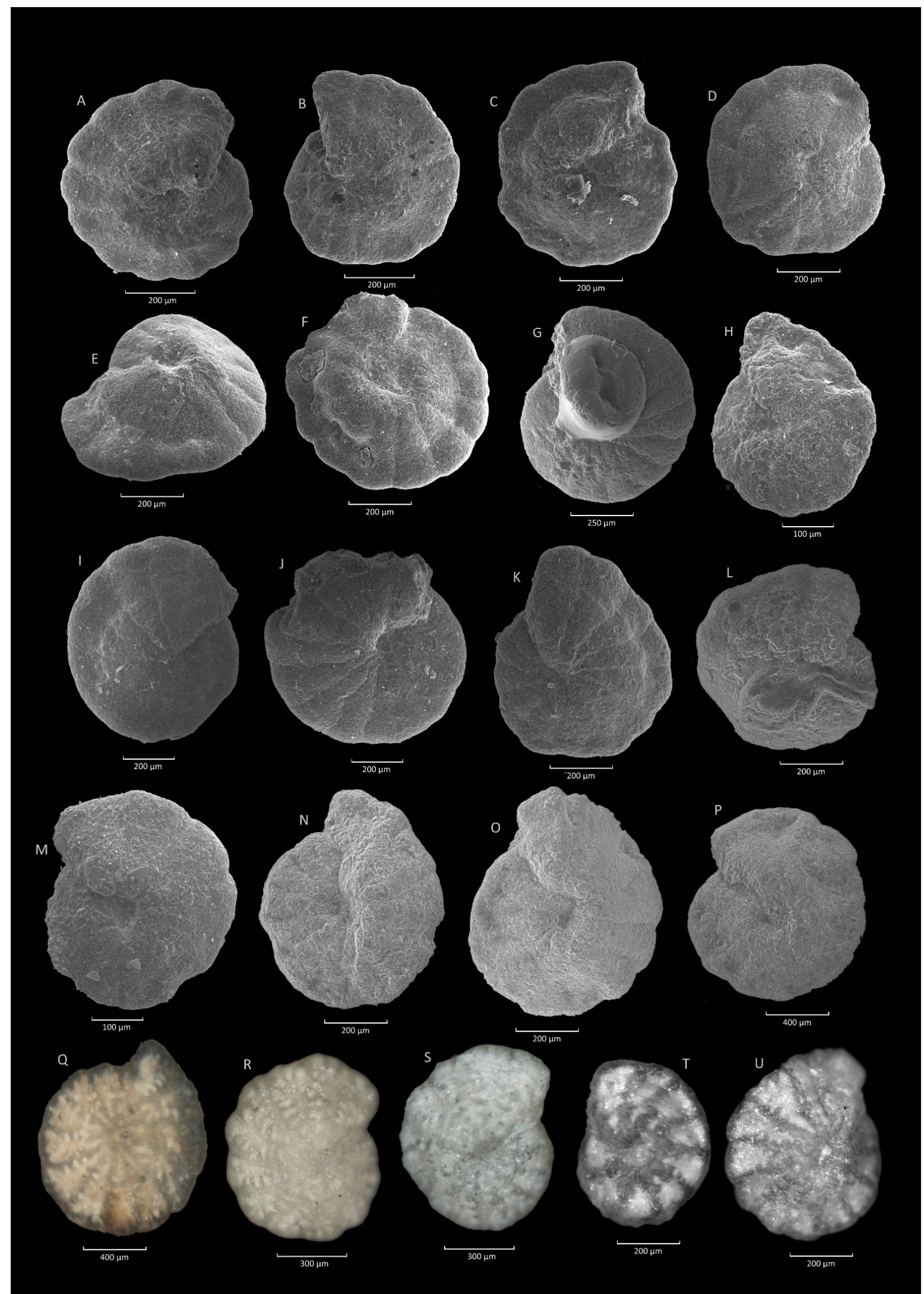

Figure 15. Reticulophragmium amplectens (Grzybowski). (A-C): Krzesławice section; (D-F): Leszczawa section; (G): PorębyCzarnotówki section; (H): Leszczawa section; (I-K): Sucha Beskidzka section; (L,M): Poręby-Czarnotówki section; (N): Lipie section; (O,P): Poręby-Czarnotówki section; (Q,R): Gorlice section; (S): Zamczysko section; (T,U): Jezioro Rożnowskie section. 


\subsubsection{Occurrence and Age Assignment}

Lutetian-lower Bartonian (Figures 3, 5 and S1), commonly in the Magura and Silesian domains.

\subsubsection{Remarks}

Reticulophragmium amplectens is the one of the most widely distributed and best known Eocene deep-water foraminifera. It is used in standard biostratigraphical zonations of the Outer Carpathians [2,3]. It occurs from the lower Eocene (e.g., [1,34,40,53,55] and references therein), with an acme in the middle Eocene. Commonly the proportion of $R$. amplectens is between 12 and $20 \%$. A maximum amount of $63 \%$ was observed in the Silesian Nappe, but the dominance of $R$. amplectens is rare.

The growth of number of $R$. amplectens specimens is observed in high-diversity assemblages. Usually, these assemblages contain plenty of foraminiferal specimens (1000 or more per $500 \mathrm{~g}$ sample). The lower part of the acme coincides with the Reticulophragmium amplectens zone [3] and is correlated with the planktonic foraminiferal scheme. In this interval, the share of $R$. amplectens is the greatest. The acme occurs also in the lower part of the Ammodiscus latus zone [3], but afterwards the number of $R$. amplectens is lower.

Abundant $R$. amplectens in the middle Eocene is reported from the Outer Carpathians. It was observed in the Magura Nappe $[16,17,19,21,26,43,53,81]$, in the Silesian Nappe [12,41,54,82-84], in the Dukla Nappe [32], in the Subsilesian Nappe [18], and in the Skole Nappe $[30,76]$. The $R$. amplectens acme is known from the Eastern Carpathians (e.g., [85-88], and from the deep-water Atlantic and North Sea [89,90]. The R. amplectens assemblages occur in different types of middle Eocene shales, the most numerous occur in red shales. It was interpreted as preferring well-oxygenated environments with a low supply of clastic material [91].

\subsection{Reophax duplex (Grzybowski)-Reophax "pilulifer" Brady Acme \\ 4.11.1. Definition}

Increased amounts of Reophax spp. specimens, particularly Reophax duplex (Grzybowski) and Reophax "pilulifer" Brady (Figures 16 and 17) are up to 5\% or more in assemblages. A relatively abundant $H$. walteri together with Haplophragmoides nauticus Kender, Kaminski et Jones co-occurs in the range of a few or less often up to a dozen percent. In the lower part of the acme, a similar quantity of $R$. amplectens is observed. Paratrochamminoides spp. are the most numerous, generally dominating the assemblage.

\subsubsection{Occurrence and Age Assignment}

Lutetian-Priabonian (Figures 3, 5 and S1), Magura, and Silesian domains.

\subsubsection{Remarks}

The R. duplex and R. "pilulifer" group of taxa occur commonly in the Cretaceous and Paleogene Outer Carpathian deposits, usually as an accessory component. Reophax occurs frequently in the middle Eocene, in high diversity assemblages, usually with over 25 species. It was treated as the R. duplex and R. "pilulifer" group. In the Carpathian deposits, a greater taxonomic diversity of Reophax is observed, but mainly two species are mentioned, e.g., common Reophax globosus Sliter is rarely mentioned. The Reophax tests tended to fragment and are usually preserved as one- to four-chamber specimens. The observed increase of Reophax spp. from 7 to $20 \%$ in the assemblages is common, rarely is it up to $30 \%$.

An increase in the abundance of Reophax is observed in a wide interval covering the Reticulophragmium amplectens, Ammodiscus latus and Reticulophragmium rotundidorstaum (=R. gerochi) zones. From Carpathian turbidites, abundant Reophax pilulifer Brady is denoted commonly, following the identification by [92]. However, the species R. pilulifer described by Brady and R. "pilulifer" from the Carpathians show different morphological features and are in need of revision [93]. 


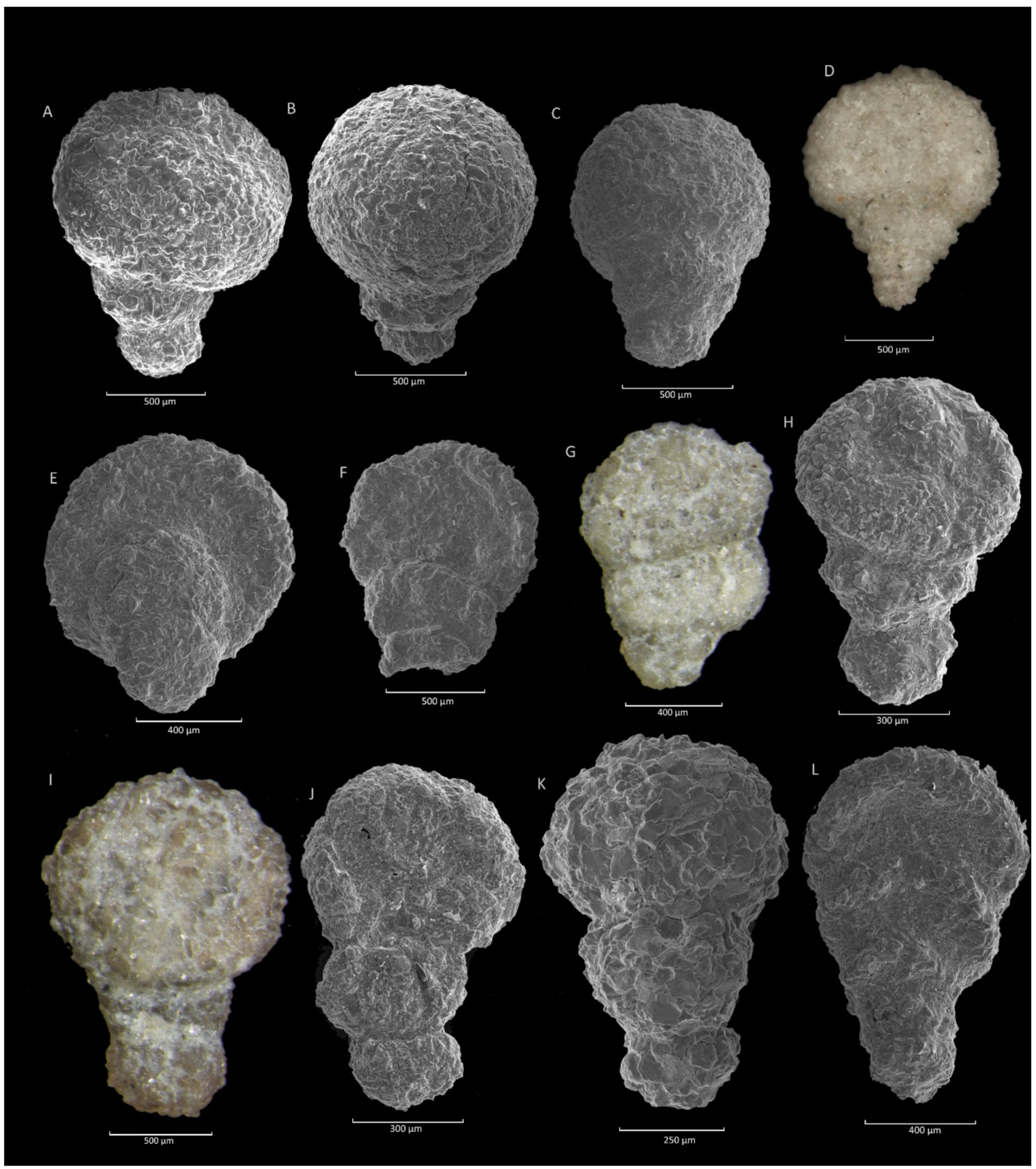

Figure 16. Reophax pilulifer type group. Reophax "pilulifer" Brady. (A,B): Krzesławice section; (C): Sucha Beskidzka section; (D): Gorlice section; (E): Rzyczki section. Reophax globosus Sliter; (F,H,I): Poręby-Czarnotówki section; (G,K): Stradomka section; (J,L): Mutne section; (L): Gorzeń section. 


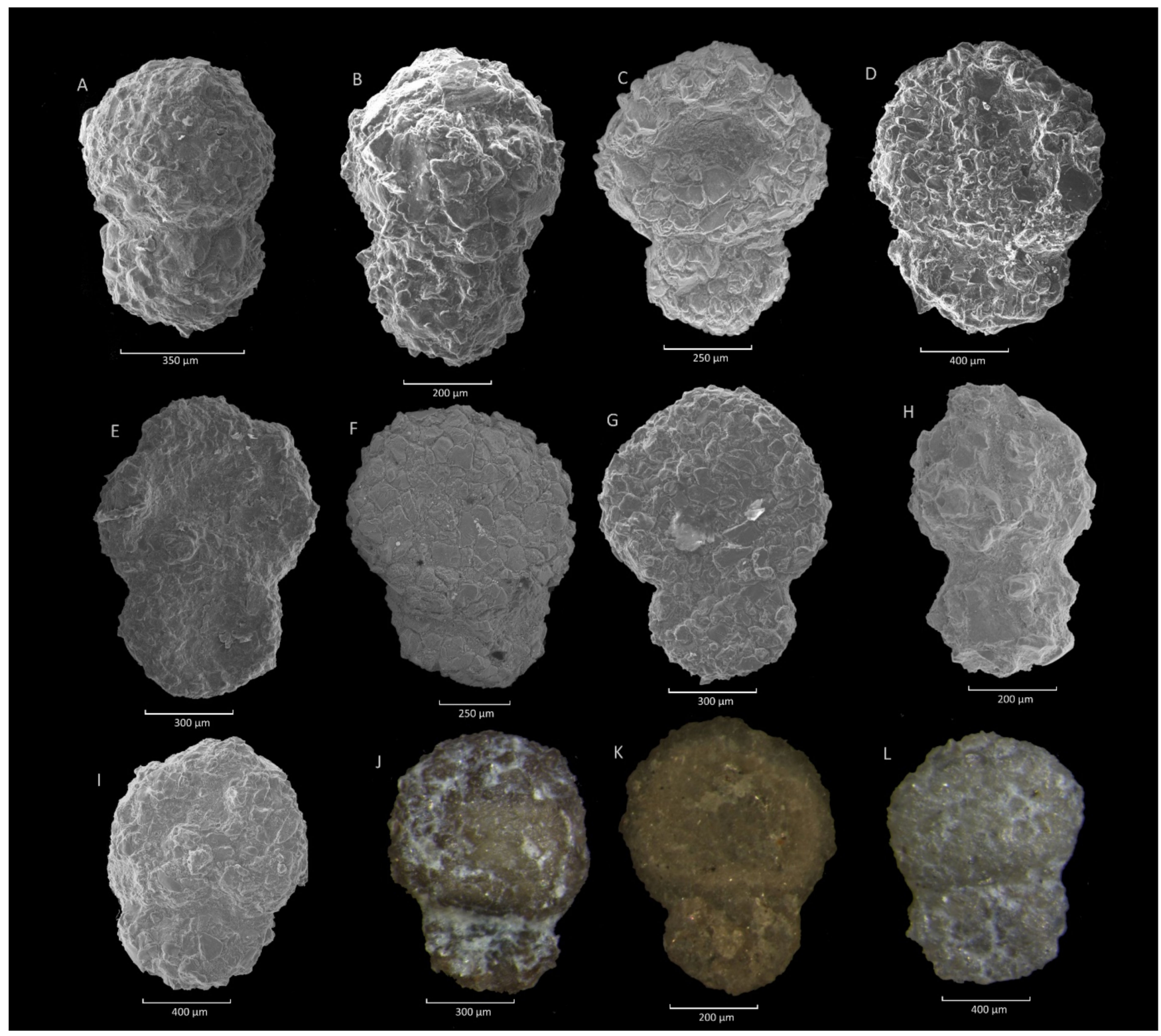

Figure 17. Reophax duplex (Grzybowski). (A): Poręby-Czarnotówki section; (B,D,G-I): Krzesławice section; (C,F): Lipie section, (E): Sucha Beskidzka section; (K): Leszczawa section; (L,J): Ropica section.

The increase in the number of Reophax was observed in the middle Eocene in both the Magura and Silesian domains $[16,19,21,23,29,34,40,41,43,53,66,76,91]$. $R$. "pilulifer", $R$. duplex, R. globosus, Reophax guttifer Brady, Reophax splendidus Grzybowski, and Reophax subnodulosus (Grzybowski) were mentioned within the Reophax group. In the Eastern Carpathians, abundances of R. pilulifer Brady were indicated from the upper part of the middle Eocene [85]. The authors of [40], next to Eocene abundance of Reophax, also mentioned an increase in the Paleocene of the Skole Nappe.

4.12. Haplophragmoides walteri (Grzybowski)-Haplophragmoides nauticus Kender, Kaminski et Jones Acme

\subsubsection{Definition}

Relative abundance of $H$. walteri-H. nauticus (Figures 18 and 19) is from $5 \%$ or more in foraminiferal assemblages. Numerous $H$. walteri or/and H. nauticus are present in two types of assemblages. In high-diversity assemblages with several dozen species, in which they usually co-occur with large-sized different species of Paratrochamminoides, and in 
low-diversified, with a few or a dozen species. Low-diversified assemblage is characterized by abundant P. subgaleata and the presence of Haplophragmoides parvulus Blaicher. Both $H$. walteri and $H$. nauticus are represented by dwarf specimens.

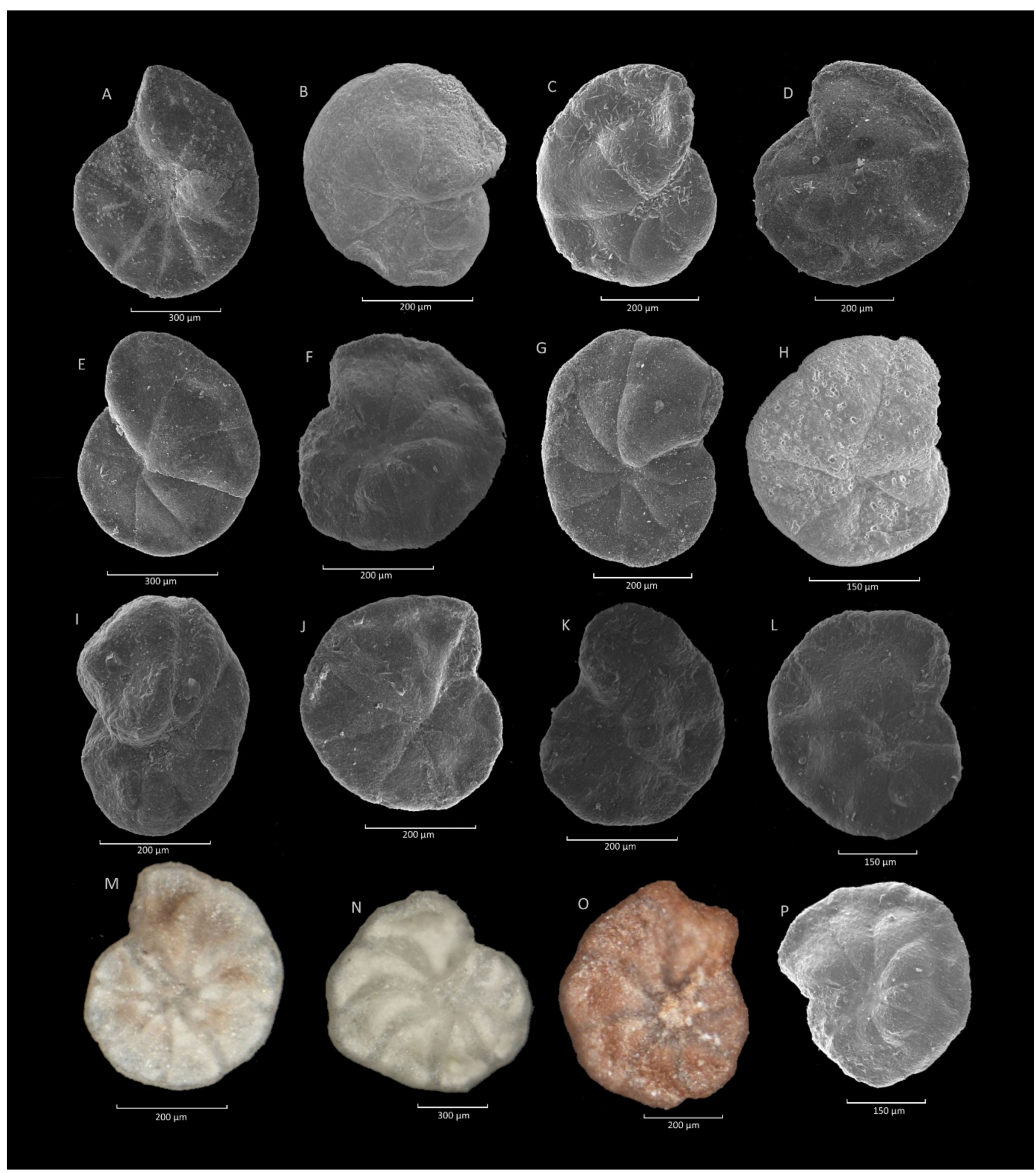

Figure 18. Haplophragmoides walteri (Grzybowski). (A,C,D,J,L,P): Krzesławice section; (B,H): Jezioro Rożnowskie section; (E,F,L): Stradomka section; $(\mathbf{G}, \mathbf{K})$ : Leszczawa section; (I): Sucha Beskidzka section; (M,N): Gorlice section; (O): Zamczysko section. 


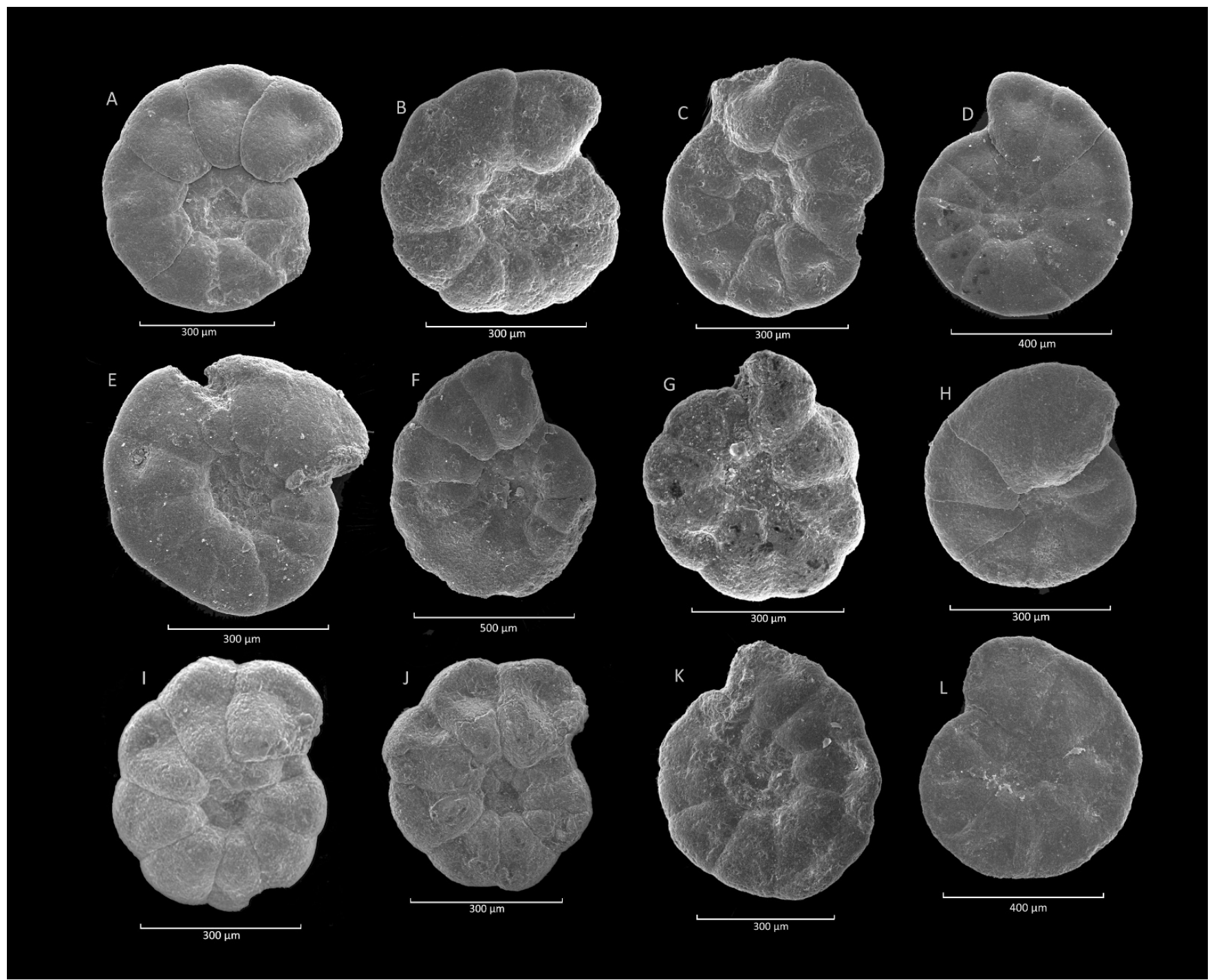

Figure 19. Haplophragmoides nauticus Kender, Kaminski et Jones. (A-F): Krzesławice section; (G): Leszczawa section; (H): Składy section; (I-K): Lipie section; (L): Składy section.

\subsubsection{Occurrence and Age Assignment}

Lutetian-Bartonian (Figures 3, 5 and S1), Silesian and Magura domains.

\subsubsection{Remarks}

The most common assemblages contain from $3 \%$ to $15 \%$ of $H$. walteri-H. nauticus. The maximum percentage (42\%) was observed in the Magura Nappe.

A high relative abundance of $H$. walteri is known from the Eocene of the Magura Nappe $[7,16,17,19,21-23,26,42,53,91]$, from the Skole Nappe [76] and from the Silesian Nappe $[28,40,82]$. In the Eastern Carpathians, an increased share was described from dark Eocene deposits [94]. H. nauticus occurs in the Outer Carpathians from the upper Paleocene, through the Eocene [95]. H. nauticus was described as a separate form in 2007 [96] and it was next reported from the Outer Carpathians [14,53,79,91,97-100]. Earlier, the species was lumped together with the $H$. walteri form. Features typical of $H$. nauticus have been documented in descriptions or photo-documentations under the name H. walteri [101,102]. In the Paleocene Rzehakina fissistomata zone, assemblages with an increased number of $H$. walteri occur ephemeral.

The relative abundance of $H$. walteri or/and $H$. nauticus occurs in different types of shales, their number significantly increases in the grey and dark grey shales. Both species 
preferred environments with significant delivery of organic matter, and were tolerant of oxygen-poor environments.

\subsection{Spiroplectammina spectabilis (Grzybowski) Acme 4.13.1. Definition}

Relative abundances of $S$. spectabilis (Figure 20) is from 5\% or more in foraminiferal assemblages. Assemblages have different taxonomic composition, usually Recurvoides spp. with Recurvoidella spp. and Paratrochamminoides spp. are abundant. Other relatively abundant taxa like $H$. nauticus, H. walteri, Karrerulina coniformis (Grzybowski), and $R$. amplectens generally do not exceed a dozen percent and occur randomly in different configurations. R. "pilulifer", and R. duplex constitute subordinate component. Typical of the $S$. spectabilis acme assemblages is the co-occurrence of an increased number, up to a few percent of large-sized G. glomerata.

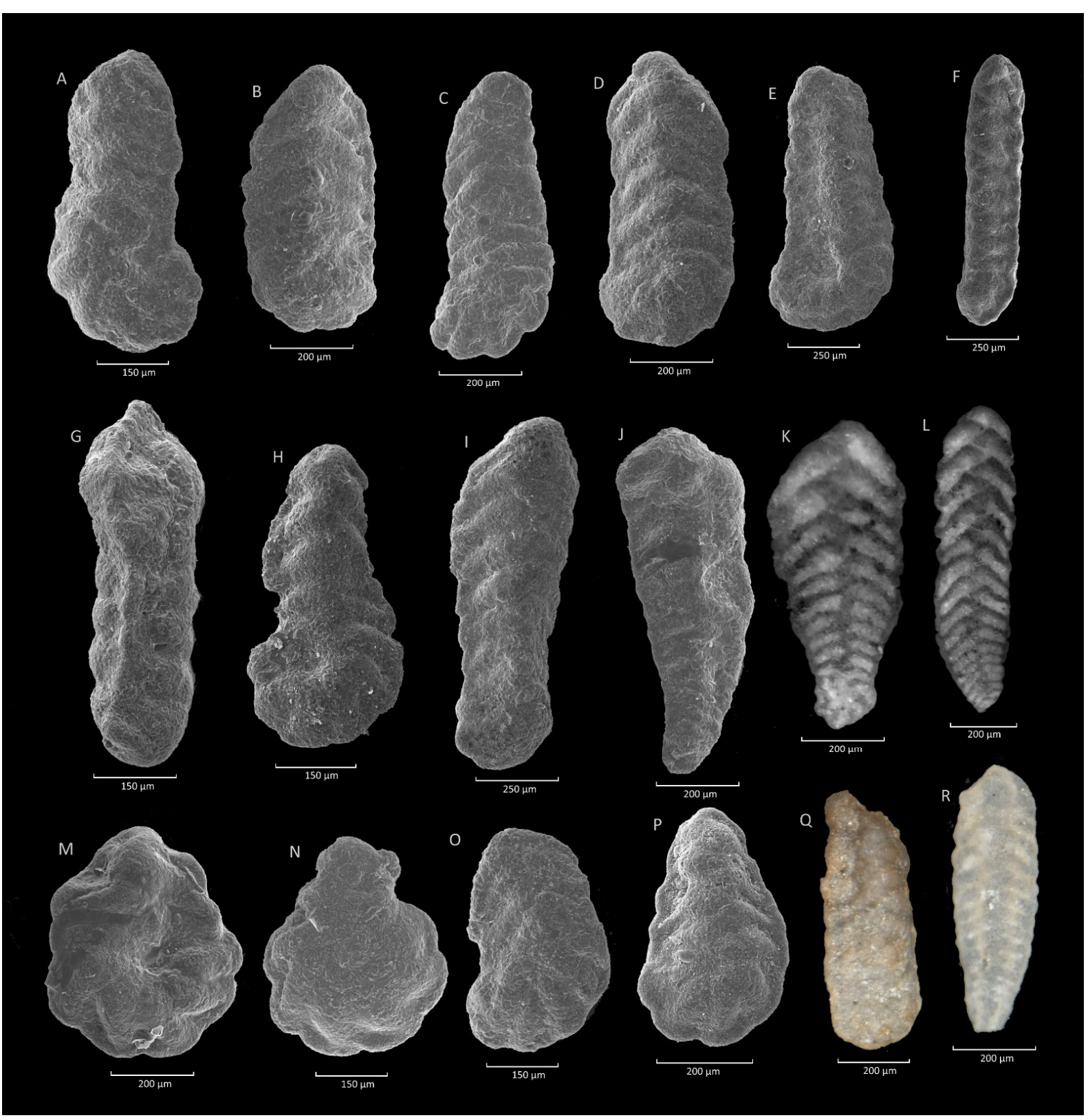

Figure 20. Spiroplectammina spectabilis (Grzybowski). (A): Jeleśnia section; (B-D): Poręby-Czarnotówki section; (E-I): Krzeszów section; (J): Jeleśnia section; (K,L): Jezioro Rożnowskie section; (M): Stradomka section; (N): Krzeszów section; (O): Jeleśnia section; (P,Q): Olecka section; $(\mathbf{R})$ : Gorlice section. 


\subsubsection{Occurrence and Age Assignment}

Lutetian-Priabonian (Figures 3, 5 and S1), Silesian Domain, rare in Magura Domain.

\subsubsection{Remarks}

S. spectabilis belongs to the most characteristic species among deep-water Carpathian foraminifera. In the Outer Carpathians, it occurs from the Maastrichtian up to the upper Eocene $[1,34,65,93,101]$. Usually it occurs in highly-diversified assemblages, with over 20 species. The share of $S$. spectabilis predominantly is from 5 to $15 \%$ in the assemblage, a maximum amount reaching 30\% was observed in the Silesian Nappe deposits.

Relatively abundant S. spectabilis are observed in the Silesian, Skole, and Subsilesian nappes in the Reticulophragmium amplectens zone and in the lower part of the Ammodiscus latus zone. It occurs in the Eocene in the Silesian Nappe $[28,40,82,89]$, and in the Skole Nappe [40,76]. A Spiroplectammina spectabilis zone marked by the dominance of S. spectabilis was distinguished in the upper Eocene of the Eastern Carpathians $[86,103]$. Mass occurrences were reported from the Paleocene in the boreal North Atlantic [89], and Trinidad [36].

An increased number in the Outer Carpathians, usually up to a few percent of $S$. spectabilis, is observed also in the upper Paleocene. H. velascoensis and different Caudammina spp. in the lower part of the Paleocene S. spectabilis acme, as well as increased numbers of Karrerulina conversa (Grzybowski) in its upper part usually co-occur. It is not so common as the Eocene acme. In different intervals of the Paleocene, an increase in S. spectabilis is commonly noted from the Atlantic-Tethyan and Boreal realms $([1,35,89,104-106]$ and references therein). It is one of the most common species in the Paleocene at Site 1511 in the Tasman Sea [69].

The S. spectabilis assemblages occur more often in green or grey shales rather than in red or variegated shales. The species preferred environments with higher sea-floor carbon flux and siliciclastic flux $[1,89]$, and it is one of the opportunistic species that formed a post-crisis acme after the Cretaceous/Paleogene boundary event [35].

\subsection{4. "Ammodiscus" latus Grzybowski Acme}

\subsubsection{Definition}

The relative abundance of "Ammodiscus" latus Grzybowski (Figure 21) ranges from 4\% in assemblages. "A." latus usually co-occurs with a relatively abundant Reophax spp. in amounts of up to $20 \%$ in low-diversity assemblages, or up to few percent in high-diversity assemblages and in some assemblages with relatively abundant, usually a few percent, of Haplophragmoides. Abundant Paratrochamminoides spp. co-occurs, ranging from 25 to $75 \%$. In some assemblages abundant Thalmannammina subturbinata (Grzybowski) and Recurvoides spp. is present, as well as P. subgaleata.

\subsubsection{Occurrence and Age Assignment}

Lutetian-Priabonian (Figures 3, 5 and S1), common in the Silesian Domain. In the Magura Domain the species is less frequent.

\subsubsection{Remarks}

"A." latus is an important stratigraphic marker widely used for dating deposits in the Outer Carpathians. The Ammodiscus latus zone has been applied in numerous papers using zonation according [2,3]. In low-diversified assemblages with several co-occurring species, the proportion amounts over a dozen or more to a few percent; in highly-diversified assemblages its proportion comes to a few percent. Usually its abundance is $5-20 \%$. A maximum proportion was observed in assemblages from the Silesian and Skole nappes where it reaches over $35 \%$ of the foraminiferal assemblage. 


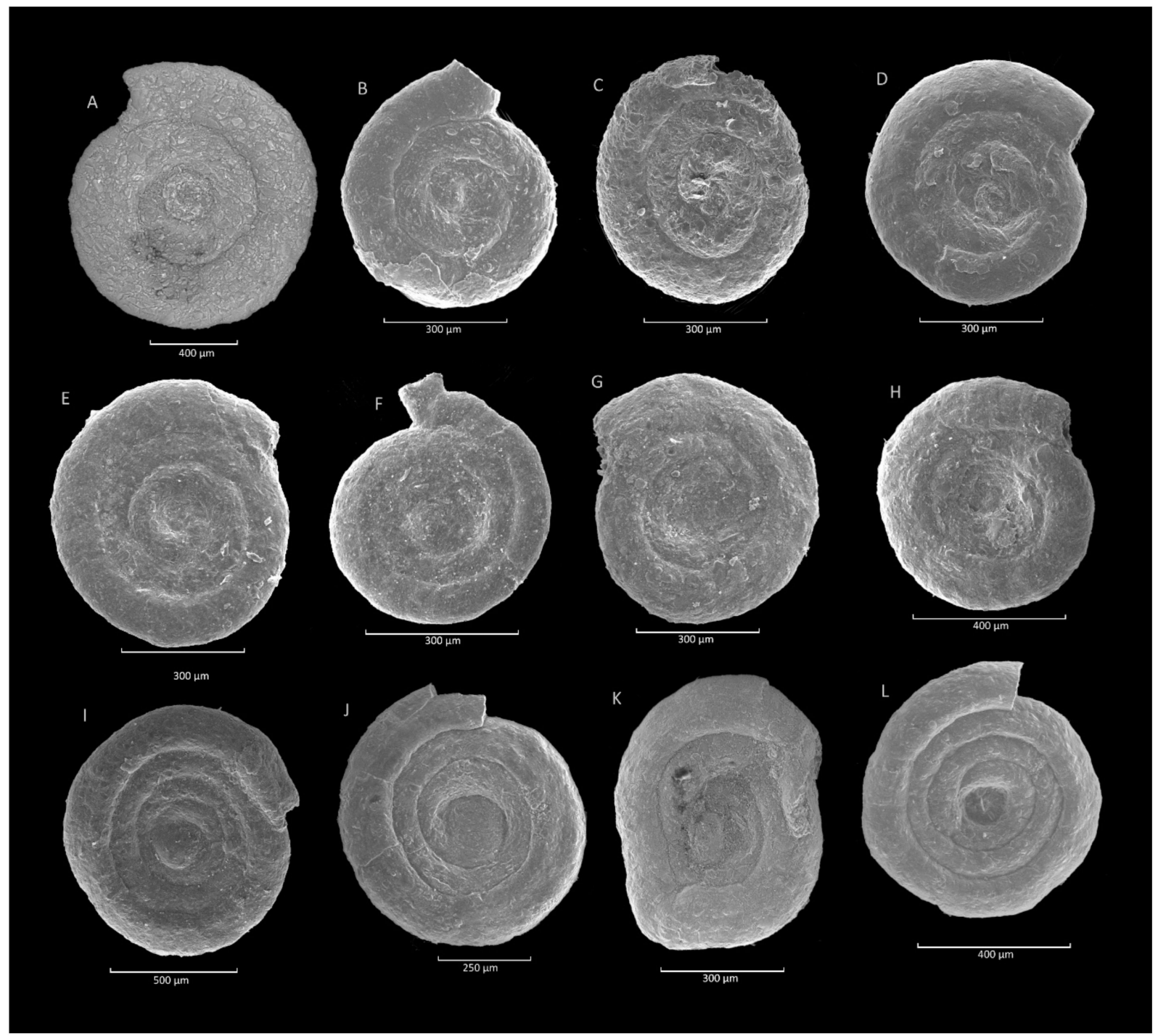

Figure 21. "Ammodiscus" latus (Grzybowski). (A-C,E,F): Krzesławice section; (D,H,I): Poręby-Czarnotówki section; (G): Leszczawa section; (J-L): Lipie section.

A high relative abundance occurs in the upper part of the Ammodiscus latus and within the Reticulophagmium rotundidorstaum (=R. gerochi) zones. Forma latus, and forma latus ovoidalis sensu [107] occur together. A taxonomical study on "A." latus indicates the need for the emendation of the Ammodiscus genera or the description of a new genus for A. latus [107].

Abundant "A." latus are known from the middle-upper Eocene $[40,108]$. The species was reported from the Silesian Nappe [41,54,82], from the Skole Nappe [30,76], from the Dukla Nappe [72] and from the Magura Nappe [19,26,109].

Assemblages with abundant "A." latus occur in different types of shales, the most numerous come from the muddy, grey deposits.

\subsection{Praesphaerammina subgaleata (Vašiček) Acme 4.15.1. Definition}

The share of $P$. subgaleata (Figure 22) is $20 \%$ and more in foraminiferal assemblages. $P$. subgaleata co-occurs with Chilostomella (usually pirityzed and mainly Chilostomella chilostomelloides Vašíček), H. paroulus, and H. walteri as well as other cosmopolitan and long-ranging foraminiferal species of the genera Nothia spp., Recurvoides spp. and Paratrochammi- 
noides spp. The accompanying species are dwarfed, except the Chilostomella spp. and tubular forms.

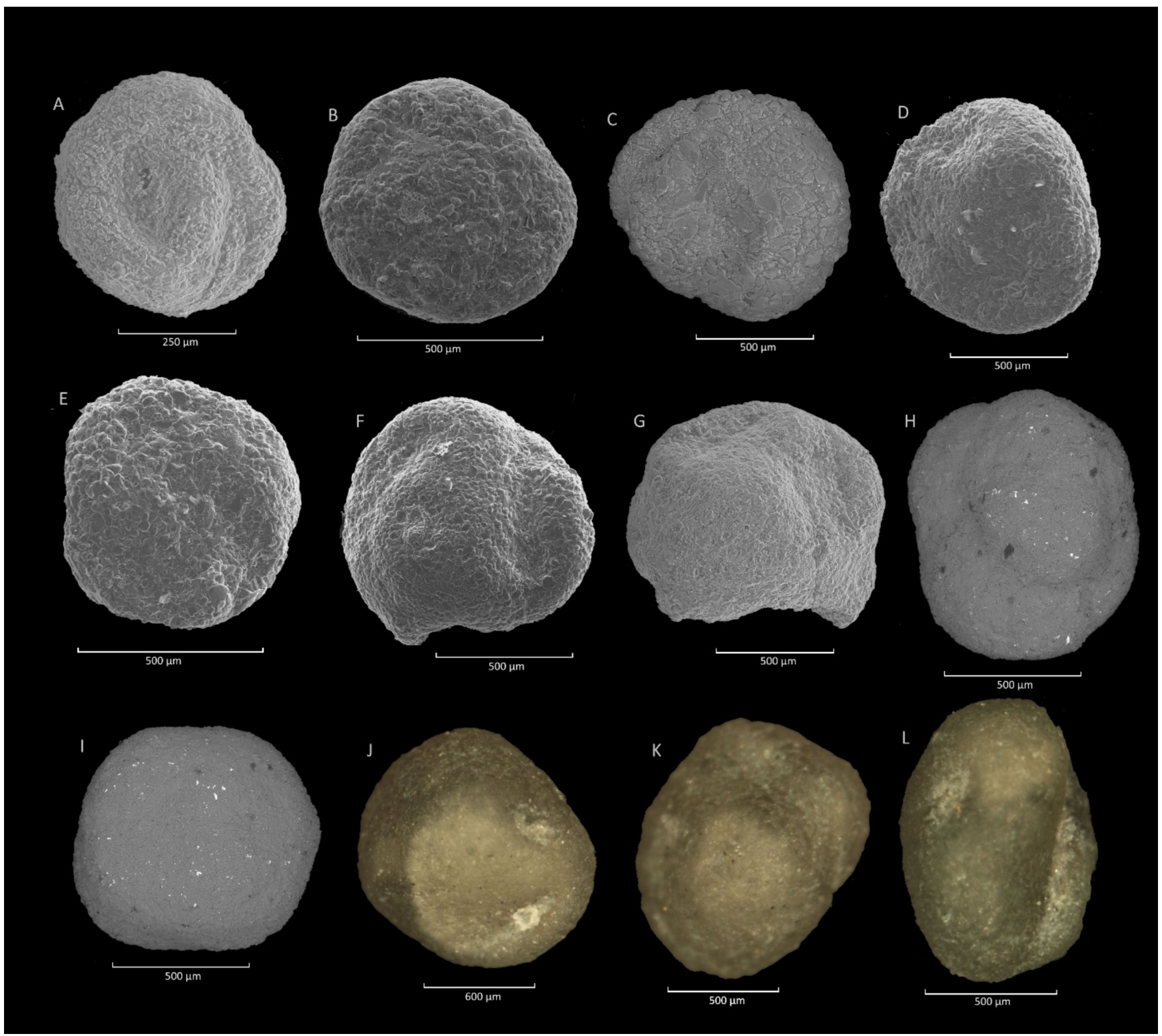

Figure 22. Praesphaerammina subgaleata (Vašǐček). (A,G): Jezioro Rożnowskie section; (B): Stradomka section; (C-F): Krzesławice section; (H,I): Mosorny section; (I-L): Klimkówka section.

\subsubsection{Occurrence and Age Assignment}

Lutetian-Bartonian (Figures 3, 5 and S1), Magura, and Silesian domains.

\subsubsection{Remarks}

P. subgaleata occurs in the Outer Carpathians from the middle Eocene $[1,10,65,99]$. It belongs to the large-sized agglutinated foraminifera among the benthic foraminifera found in deep-water turbidites. Its stratigraphic position was constrained based on agglutinated foraminiferal zonations, and correlated with nannoplankton and planktonic foraminiferal zones $[97,110]$. The quantity of $P$. subgaleata oscillates usually from $60 \%$ up to $90 \%$ in the Magura Domain. Completely monospecific assemblages are rare. The assemblages are lowdiversified, with a few or just over a dozen species. In the Silesian Domain, the number of $P$. subgaleata is lower. P. subgaleata constitutes several dozen percent of assemblage and occurs 
within the higher-diversified assemblages. The increase in taxonomic diversity is clearly connected with the decrease in the amount of P. subgaleata and dwarfed foraminifera.

The abundance of P. subgaleata has been used repeatedly in Outer Carpathian biostratigraphy. The P. subgaleata assemblages in the middle-upper Magura Eocene deposits are common $[12,16,17,21,22,26,34,42,43,53,99,110-117]$. Abundant $P$. subgaleata are known from the Subsilesian Nappe deposits also [12,28,40]. Nearly monospecific assemblages were also reported from the Eastern Carpathians [118].

In the older literature, abundance of $P$. subgaleata were also noted in the Paleocene $[12,18,34,40,71]$. However, up to the 1970 s, the species P. gerochi and P. subgaleata were lumped together as a single taxon. Therefore, the Paleocene acme is due to the species $P$. gerochi.

P. subgaleata occurred in environments with oxygen deficiency with an increased amount of organic matter [7,22,112]. It is found in grey shales, among the species withstanding low oxygenation and with a large amount of pyrite in sediments.

\section{Discussion}

The increase in the abundance of a given taxon is an ecological phenomenon. Acmes mentioned above represent two groups. The first group consists of common and cosmopolitan long-ranging species whose relative abundance increased temporary because of regional/global environmental changes. The changes introduced favourable conditions for their development. Therefore, the opportunistic forms like G. charoides, G. gordialis, $P$. placenta, S. grzybowskii, R. duplex, R. "pilulifer", and H. walteri belong to this group (Figure 3). They are known from the fossil record from more than $150 \mathrm{Ma}$ up to about $60 \mathrm{Ma}$, while their acmes lasted from about 4 to $12 \mathrm{Ma}$ (Figure 3). It is a short time in relation to their total range. The second group embraces short-ranging species, and their abundances are related to the main phase of species development-its maximum spread (Figure 1 in [119]) under favourable ecological conditions. The species $C$. gigantea, C. excelsa, C. ovulum, C. ovuloides, H. velascoensis, P. gerochi, R. amplectens, H. nauticus, "A." latus, and P. subgaleata belong to this group. Maximum spread begins with a rapid increase in quantity and ends with a rapid decrease. The acme covered a significant interval of the species range and lasted from $22 \mathrm{Ma}$ in case of longer-ranging species (e.g., C. ovulum) up to $5 \mathrm{Ma}$ in the case of shorter-ranging species (e.g., P. subgaleata). The prevailing ecological conditions determined the structure of benthic foraminiferal assemblage. Favourable conditions for species acmes are connected with the presence of a factor or group of factors in the environment that causes the optimal development of the species. This is characteristic for well-diversified assemblages. As a rule, along with the growth in taxonomic diversity, the number of species in an acme decreases. Ecological limits to the development of other co-occurring species also made opportunities for settlement of the available ecological niches by opportunistic taxa. The dominance of one or more species in an acme and nearly monospecific assemblages like Trochammina sp., G. charoides-G. gordialis, P. subgaleata, or P. gerochi are results of ecological crises and environmental restrictions. This type is short-ranging acme that typically lasted only a few million years.

The presented data do not cover all the relevant species of an acme. There are still a few that require further investigation. These include $A$. pseudopauciloculata numerous in the middle Eocene and also in the late Paleocene, the Paratrochamminoides group, in particular, the numerous occurrence of large-sized forms in the uppermost lower Paleocene and upper Paleocene, as well as Karrerulina spp., Thalmannammina subturbinata (Grzybowski), and Recurvoidella lamella (Grzybowski) that number increased in the Eocene.

Observation of the sequence of occurrences and registration of species diversity not only in terms of the appearance or disappearance of taxa, but also in terms of changes in their number can have biostratigraphical significance. In the Carpathian biozonations based on agglutinated foraminifera, acmes have had a limited importance. Zones are based on species ranges and the most important is the first appearance of a taxon. In the Santonian-Eocene, four acme zones were proposed [3] (Figure 3): Caudammina gigantea, 
Rzehakina inclusa, Glomospira div. sp., and Saccamminoides carpathicus zones. In practice, only the Glomospira div. sp. zone is commonly used. The definition of these zones does not explain what is exactly considered acme. An open descriptive definition has been used and acme is defined as "interval of numerous occurrence, frequent occurrence or abundant occurrence of the index species", which in practice for R. inclusa or Saccamminoides carpathicus Geroch means more than a few specimens per sample, but it is still a marginal amount, well below $1 \%$ in the assemblage. Earlier, there were indicated intervals with an increased amount of over a dozen species, used as index forms in the proposed biostratigraphy [34]. C. gigantea, G. charoides, G. gordialis, R. amplectens, R. pilulifer, and P. subgaleata were among them. The number of species useful in biostratigraphy can be increased by including $P$. placenta, S. grzybowskii, R. duplex, H. walteri, S. spectabilis, C. excelsa, C. ovulum, C. ovuloides, H. velascoensis, P. gerochi, H. nauticus, and "A." latus (Figure 3).

Problems in the biostratigraphy of the Outer Carpathians are connected with low taxonomical variability of the foraminiferal assemblages, which contain cosmopolitan and mostly long-ranging agglutinated taxa. With the exception of the Glomospira acme zone, agglutinated foraminiferal biozonations in the Outer Carpathians are based on occurrence of the relatively short-ranging species. Main index species like $R$. inclusa, $R$. fissistomata, $S$. carpathicus, and R. gerochi are accessory components of assemblages, present in assemblages in very low numbers, usually as single specimens. Limitations of research processes related to the sample volume result in the lack of diagnostic biomarkers, despite their presence in the sediment. Such situations are commonly noted, therefore in continuous sections the index species are present only in some samples in the continuous sequence within the distinguished foraminiferal zone. The recognition of acmes is an alternative that can be used in biostratigraphy separately or as supplement together with classic zonation. Acmes has the following features as biostratigraphical tools: (1) they are common, (2) they are widely distributed in the Outer Carpathian units, (3) they occur in limited stratigraphic interval, and (4) they are easily identified. Especially commonness of occurrence is a feature of great importance, which favour the use in biostratigraphy. The possibility to increase the accuracy of biostratigraphic dating by using acmes is a challenging problem. Compiling the currently used biostratigraphic zonations based on the studies of [2,3] with periods of increased occurrence of species can provide additional detail to the biostratigraphic subzonations. In Campanian-Paleocene time, significant changes in the agglutinated assemblages took place. Both the taxonomic composition and the assemblage structure were changing. The acme boundaries of Caudammina, Hormosina, and Placentammina with Saccammina occurred within the Rzehakina inclusa and Rzehakina fissistomata zones. The application of both first occurrences and acmes in biostratigraphy gives a chance to improve the zonal scheme by subdividing the biozones into subzones based on an acme. It will be important to precisely determine the periods of acmes of short-ranging species, as it is suitably younger than the first occurrence of the species.

The use of acme also has limitations. Ames are related to environmental changes and both opportunistic species and long-ranging ones occur in acmes. The presented acmes are the result of regional changes that occurred in the different Carpathian units. However, it should be taken into account that in other time periods the local, rapid, and very shortranged environmental change can result in ephemeral grow of individual amounts of species in assemblages.

Two domains occurred in the Outer Carpathian basins during the Cretaceous and Paleogene. They were separated by the Silesian Ridge and constituted individual areas with individual sedimentary history and sedimentary cover (Figures 1 and 5). The majority of the discussed acmes occur in both domains and have regional range (Figure 5). All acmes are observed in the Silesian Domain. In the Magura Domain only 13 acmes were observed. Currently, C. ovuloides and Trochammina acmes were found only in the Silesian Domain. Differences between the acme development are connected with specific ecological and sedimentological conditions in each domain. Differences are connected with the share of individual acme species and frequency of acme assemblages. In the Magura Domain, 
the species P. subgaleata, Glomospira, and C. excelsa are more numerous in acme assemblages, in turn, P. gerochi, S. spectabilis, and A. latus are more abundant and common in the acmes in the Silesian Domain. In the Silesian Nappe, there is an acme gap within the Istebna Formation. This formation is predominated by thick- and very thick-bedded sandy and conglomeratic turbidites and its micropaleontological record is very poor. The acme gap is due to the lack of conditions for proper foraminiferal development or fossil preservation. Data from the Dukla Nappe do not show the full spectrum of acmes. The sampling of this unit was not systematic against the Cretaceous and Paleogene deposits and does not give a proper picture of the foraminiferal record. Published micropaleontological data $[30,32,55,76]$ indicate increased numbers of taxa in time intervals, i.e., Glomospira, Trochammina, R. amplectens, and A. latus which refers to acmes in other structural units.

\section{Conclusions}

In the Outer Carpathians, the intervals of the agglutinated foraminiferal acmes are a support or an alternative for standard biozones currently in use. Within the CampanianEocene interval, 15 acmes are distinguished: Caudammina gigantea (Geroch) (uppermost Santonian-lowermost Maastrichtian), Caudammina ovulum (Grzybowski) (CampanianDanian), Placentammina placenta (Grzybowski)-Saccammina grzybowskii (Schubert) (upper Campanian-Danian), Caudammina excelsa (Dylążanka) (lowermost MaastrichtianDanian), Caudammina ovuloides (Grzybowski) (Danian-lower Selandian), Hormosina velascoensis (Cushman) (upper Danian-Selandian), Praesphaerammina gerochi (Hanzlíková) (Thanetian), Glomospira charoides (Jones et Parker)-Glomospira gordialis (Jones et Parker) (uppermost Thanetian-lower Ypresian), Trochammina sp. (upper Thanetian-lower Ypresian), Reticulophragmium amplectens (Grzybowski) (Lutetian-Bartonian), Reophax duplex (Grzybowski)-Reophax "pilulifer" Brady (Lutetian-Priabonian), Haplophragmoides walteri (Grzybowski)-Haplophragmoides nauticus Kender, Kaminski et Jones (LutetianBartonian), Spiroplectammina spectabilis (Grzybowski) (Lutetian-lower Priabonian), "Ammodiscus" latus Grzybowski (Bartonian-Priabonian), and Praesphaerammina subgaleata (Vašíček) (upper Lutetian-Priabonian).

The agglutinated foraminiferal acmes are related to the environmental conditions. In detail, the presence of suitable conditions for the development of the accessory species resulted in their increased abundance in the amount of at least a few percent or more. The Carpathian acmes intervals lasted from 4 to $22 \mathrm{Ma}$. The shortest-ranging acmes, lasting several Ma, were associated to post-crisis assemblages where opportunistic taxa settled the free niches. The nearly monospecific assemblages or assemblages with a single dominant taxon are typical of such intervals. Less numerous are longer-ranging acmes. They were connected with introducing favourable conditions for development of selected taxa or groups of taxa. Acme species occurred within more taxonomically diversified assemblages in amounts from a few percent. The Carpathian acmes are characterised by the occurrence of the cosmopolitan deep water species, both long-ranged (lived 60 Ma or more) and relatively short-ranged species.

The described agglutinated foraminiferal acme intervals are easy to identify and provide a biostratigraphical tool at regional scale for the Outer Carpathian sedimentary sequences. The Silesian and Magura domains display repeatability in the sequence of acmes. A more complete acme sequence with 15 acmes is found in the Silesian Domain. In the Magura Domain, 13 acmes were observed. The Caudammina ovuloides and Trochammina sp. acmes have been found only in the Silesian Domain.

Supplementary Materials: The following are available online at https:/ / www.mdpi.com/article/10 .3390 /geosciences11090367/s1, Figure S1. Percent share and litho- and biostratigraphic distribution of species occurring in acmes in the Outer Carpathian foraminiferal assemblages.

Funding: This research was funded by AGH University of Science and Technology subsidy funds no. 16.16. 140. 315 and supported by Micropress Europe Foundation.

Institutional Review Board Statement: Not applicable. 
Informed Consent Statement: Not applicable.

Data Availability Statement: The data presented in this study are available upon request from the author.

Acknowledgments: I thank Aleksandra Durek (AGH) and Teresa Wójcik (AGH) for laboratory work. I would like to express my thanks to the Reviewers for their valuable advice and tips. I am very grateful to Michael A. Kaminski for discussions and the comments on the text and the linguistic proofreading.

Conflicts of Interest: The author declares no conflict of interest. The funders had no role in the design of the study; in the collection, analyses, or interpretation of data; in the writing of the manuscript, or in the decision to publish the results.

\section{References}

1. Kaminski, M.A.; Gradstein, F.M. Atlas of Paleogene Cosmopolitan Deep-Water Foraminifera; Grzybowski Foundation, Grzybowski Foundation Special Publication: Kraków, Poland, 2005; Volume 10, pp. 1-547.

2. Geroch, S.; Nowak, W. Proposal of zonation for the Late Tithonian-Late Eocene, based upon arenaceous Foraminifera from the Outer Carpathians, Poland. In Proceedings of the BENTHOS '83: 2nd International Symposium on Benthic Foraminifera, Pau, France, 11-15 April 1983; Oertli, H.J., Ed.; ESO REP and TOTAL CFP: Pau and Bordeoux, Elf-Aquitane, France, 1984; pp. 225-239.

3. Olszewska, B. Foraminiferal biostratigraphy of the Polish Outer Carpathians: A record of basin geohistory. Ann. Soc. Geol. Pol. 1997, 67, 325-337.

4. Golonka, J.; Gahagan, L.; Krobicki, M.; Marko, F.; Oszczypko, N.; Ślączka, A. Plate tectonic evolution and paleogeography of the Circum-Carpathian region. In The Carpathians and Their Foreland: Geology and Hydrocarbon Resources; Golonka, J., Picha, F., Eds.; American Association of Petroleum Geologists: Tulsa, OK, USA, 2006; Volume 84, pp. 11-46.

5. Golonka, J.; Waśkowska, A.; Ślączka, A. The Western Outer Carpathians: Origin and evolution. Zeitsch. Deut. Gesell. Geowiss. 2019, 170, 229-254. [CrossRef]

6. Golonka, J.; Gawęda, A.; Waśkowska, A. Carpathians. In Reference Module in Earth Systems and Environmental Sciences, Encyclopedia of Geology, 2nd ed.; Elsevier: Amsterdam, The Netherlands, 2020; pp. 372-381. [CrossRef]

7. Oszczypko, N.; Uchman, A.; Malata, E. Palaeotectonic Evolution of the Outer Carpathian and Pieniny Klippen Belt Basins; Instytut Nauk Geologicznych UJ: Kraków, Poland, 2006; pp. 1-199.

8. Książkiewicz, M. Tectonics of the Carpathians. In Geology of Poland. Vol. IV. Tectonics; Pożaryski, W., Ed.; Wydawnictwa Geologiczne: Warszawa, Poland, 1977; pp. 476-604.

9. Lexa, J.; Bezák, V.; Elečko, M.; Mello, J.; Polák, M.; Potfaj, M.; Vozár, J. Geological Map of Western Carpathians and Adjacent Areas 1: 500,000; Geological Survey of Slovak Republic: Bratislava, Slovakia, 2000.

10. Bubik, M. Remarks on the quantitative analysis of deep-sea agglutinated foraminiferal taphocoenoses with special attention to tubular astrorhizids. Micropaleontology 2019, 65, 63-74.

11. Gradstein, F.M.; Ogg, J.G.; Schmitz, M.D.; Ogg, G.M. Geologic Time Scale 2020; Elsevier: Amsterdam, The Netherlands, 2020; pp. 1-1357.

12. Geroch, S.; Jednorowska, A.; Książkiewicz, M.; Liszkowa, J. Stratigraphy based upon microfauna in the Western Polish Carpathians. Biul. Inst. Geol. 1967, 211, 185-282.

13. Malinowska, L. Budowa Geologiczna Polski, T.3, Atlas Skamieniałości Przewodnich i Charakterystycznych, cz. 2c, Mezozoik, Kreda; Wydawnictwa Geologiczne: Warszawa, Poland, 1984; pp. 1-579.

14. Waśkowska-Oliwa, A. The Paleocene assemblages of agglutinated foraminifera from deep-water basin sediments of the Carpathians (Subsilesian Unit, Poland)-Biostratigraphical remarks. In Proceedings of the Seventh International Workshop on Agglutinated Foraminifera; Hart, M., Kaminski, M.A., Smart, C., Eds.; Grzybowski Foundation, Special Publication: Kraków, Poland, 2008; Volume 13, pp. 227-265.

15. Waśkowska, A.; Golonka, J.; Starzec, K.; Cieszkowski, M. Campanian-Paleocene Jaworzynka Formation in its type area (Magura Nappe, Outer Carpathians). Acta Geol. Pol. 2021, 71, 345-370. [CrossRef]

16. Bieda, F.; Jednorowska, A.; Książkiewicz, M. Stratigraphy of the Magura Series around Babia Góra. Biul. Inst. Geol. 1967, 211, 293-325.

17. Bleicher, J. Mikrofauna serii magurskiej okolic Grybowa. Kwart. Geol. 1958, 2, 285-399.

18. Geroch, S.; Gradzinski, R. Stratygrafia serii podślaskiej żywieckiego okna tektonicznego. Rocz. Pol. Tow. Geol. 1955, $24,1-62$.

19. Jednorowska, A. Zespoły małych otwornic w warstwach jednostki magurskiej rejonu Babiej Góry i ich znaczenie stratygraficzne. In Przewodnik XXXIX Zjazdu Polskiego Towarzystwa Geologicznego_-Babia Góra; Wydawnictwa Geologiczne: Warszawa, Poland, 1966; pp. 71-90.

20. Lemańska, A. Comparison of deep-water agglutinated foraminiferafrom the hemipelagic variegated shales (Lower TuronianLower Santonian) and the turbiditic Godula beds (Upper Santonian-Campanian) in the Lanckorona-Wadowice area (Silesian Unit, Outer Carpathians, Poland). Stud. Geol. Pol. 2005, 124, 259-272. 
21. Malata, E. The stratigraphy of the Magura Nappe in the Western part of the Beskid Wysoki Mts., Poland based on microfauna. Biul. Inst. Geol. 1981, 331, 103-116.

22. Malata, E. Albian-Early Miocene foraminiferal assemblages of the Magura Nappe (Polish Outer Carpathians). Geol. Carpath. 2002, 53, 77-79.

23. Malata, E.; Malata, T.; Oszczypko, N. Litho- and biostratigraphy of the Magura Nappe in the eastern part of the Beskid Wyspowy Range (Polish Western Carpathians). Ann. Soc. Geol. Pol. 1996, 66, 269-284.

24. Oszczypko, N.; Dudziak, J.; Malata, E. Stratygrafia osadów płaszczowiny magurskiej (kreda-paleogen) w Beskidzie Sądeckim, Karpaty Zewnętrzne. Stud. Geol. Polon. 1990, 97, 109-181.

25. Oszczypko, N.; Malata, E.; Bąk, K.; Kędzierski, M.; Oszczypko-Clowes, M. Lithostratigraphy and biostratigraphy of the Upper Albian-Lower/Middle Eocene flysch deposits in the Bystrica and Rača subunits of the Magura Nappe (Beskid Wyspowy and Gorce Ranges; Poland). Ann. Soc. Geol. Pol. 2005, 75, 27-69.

26. Sikora, W.; Żytko, K.; Sikora, W.; Żytko, K. Budowa Beskidu Wysokiego na południe od Żywca. Biul. Inst. Geol. 1960, 141, 61-204.

27. Stráník, Z.; Bubík, M.; Švábenická, L. Oráztockých vrstvách račanské jednotky na listu 25-314 Otrokovice. Geol. Výzk. Morav. Slez. 2016, 7, 74-76.

28. Geroch, S. Microfaunal assemblages from the Cretaceous and Paleogene Silesian unit in the Beskid Slaski Mountains. Biul. Inst. Geol. 1960, 153, 1-138.

29. Kepińska, B. Subdivision of the Upper Cretaceous and Paleocene in central part of the Brzanka-Liwocz fold (Silesian Unit). Geo. Quart. 1986, 30, 63-76.

30. Olszewska, B. Stratigraphy of the middle part of the Dukla Unit in the Polish Carpathians based on foraminifera (Upper Cretaceous-Paleogene). Biul. Inst. Geol. 1980, 326, 59-97.

31. Waśkowska, A.; Joniec, A.; Kotlarczyk, J.; Siwek, P. The Late Cretaceous fucoid marl of the Ropianka Formation in the Kąkolówka structure (Skole Nappe, Outer Carpathians, Poland)—lithology and foraminiferal biostratigraphy. Ann. Soc. Geol. Pol. 2019, 89, 259-284. [CrossRef]

32. Ślączka, A. Geologia jednostki dukielskiej. Pr. Inst. Geol. 1971, 63, 1-97.

33. Bak, K. Biostratigraphy of deep-water agglutinated Foraminifera in Scaglia Rossa-type deposits of the Pieniny Klippen Belt, Carpathians, Poland. In Proceedings of the Fifth International Workshop on Agglutinated Foraminifera, Plymouth, UK, 6-16 September 1997; Hart, M., Kaminski, M.A., Smart, C.W., Eds.; Grzybowski Foundation, Special Publication: Kraków, Poland, 2000; Volume 7, pp. 15-41.

34. Morgiel, J.; Olszewska, B. Biostratigraphy of the Polish External Carpathians Based on agglutinated foraminifera. Micropaleontology 1981, 27, 1-30. [CrossRef]

35. Kuhnt, W.; Moullade, M.; Kaminski, M.A. Upper Cretaceous, K/T boundary, and Paleocene agglutinated foraminifers from Hole 959D (Côte d'Ivoire-Ghana transform margin). In Proceedings of the Ocean Drilling Program: Scientific Results; Ocean Drilling Program: Austin, TX, USA, 1998; Volume 159, pp. 389-411.

36. Kuhnt, W.; Geroch, S.; Kaminski, M.A.; Moullade, M.; Neagu, T. Upper Cretaceous Abyssal Claystones in the North Atlantic and the Western Tethys-urrent Status of Biostratigraphical Correlation using Agglutinated Foraminifers. Cret. Res. 1992, 13, 467-478. [CrossRef]

37. Moullade, M.; Kuhnt, W.; Thurow, J. Agglutinated benthic foraminifers from Upper Cretaceous variegated clays of the North Atlantic Ocean (DSDP Leg 93 and ODP Leg 103). In Proceedings of the Ocean Drilling Program: Scientific Results; Ocean Drilling Program: Austin, TX, USA, 1988; Volume 103, pp. 349-377.

38. Setoyama, E.; Kaminski, M.A.; Tyszka, J. Late Cretaceous agglutinated foraminifera and implications for the biostratigraphy and palaeobiogeography of the southwestern Barents Sea. In Proceedings of the Eighth International Workshop on Agglutinated Foraminifera, Cluj-Napoca, Romania, 7-13 September 2008; Bubík, M., Kaminski, M.A., Eds.; Grzybowski Foundation Special Publication: Kraków, Poland, 2011; Volume 16, pp. 251-309.

39. Kaminski, M.A.; Cetean, C.G.; Balc, R.; Coccioni, R. Upper Cretaceous Deep-Water Agglutinated Foraminifera from the Contessa Highway Section, Umbria-Marche Basin, Italy: Taxonomy and Biostratigraphy. In Proceedings of the Eighth International Workshop on Agglutinated Foraminifera, Cluj-Napoca, Romania, 7-13 September 2008; Kaminski, M.A., Filipescu, S., Eds.; Grzybowski Foundation, Special Publication: Kraków, Poland, 2011; Volume 16, pp. 71-106.

40. Jurkiewicz, H. Otwornice paleogenu podmenilitowego polskich Karpat Środkowych. Biul. Inst. Geol. 1967, $210,5-103$.

41. Jurkiewicz, H. Poziomy otwornicowe paleogenu wschodniej części jednostki śląskiej. Ann. Soc. Geol. Pol. 1959, $29,235-263$.

42. Książkiewicz, M. Stratygrafia serii magurskiej w Beskidzie Średnim. Startigraphy of the Magura Series North of the Babia Góra, Western Carpathians. Biul. Inst. Geol. 1958, 135, 43-82.

43. Sikora, W. Budowa geologiczna płaszczowiny magurskiej między Szymbarkiem Ruskim a Nawojową. Biul. Inst. Geol. 1970, 235, 5-121.

44. Waśkowska, A.; Golonka, J.; Machowski, G.; Pstrucha, E. Potential source rocks in the Ropianka Formation of the Magura Nappe (Outer Carpathians, Poland)—geochemical and foraminiferal case study. Geol. Geoph. Environ. 2018, 44, 49-68. [CrossRef]

45. Hnylko, S.; Hnylko, O. Foraminiferal stratigraphy and palaeobathymetry of Paleocene-lowermost Oligocene deposits (Vezhany and Monastyrets nappes, Ukrainian Carpathians). Geol. Quart. 2016, 60, 77-105. [CrossRef] 
46. Țabără, D.; Slimani, H.; Mare, S.; Chira, C.M. Integrated biostratigraphy and palaeoenvironmental interpretation of the Upper Cretaceous to Paleocene succession in the northern Moldavidian Domain (Eastern Carpathians, Romania). Cret. Res. 2017, 77, 102-123. [CrossRef]

47. Hanzlíková, E. Paleogene stratigraphy and foraminifera of the Outer Flysch Belt. Miscell. Micropal. Knihov. Zemn. Plynu Nafty 1983, 4, 43-70.

48. Beckmann, J.P.; Bolli, H.M.; Kleboth, P.; Proto-Decima, F. Micropaleontology and biostratigraphy of the Campanian to Paleocene of the Monte Giglio, Bergamo Province, Italy. Mem. Sc. Geol. 1982, 35, 91-172.

49. Cieszkowski, M.; Golonka, J.; Waśkowska-Oliwa, A.; Chodyń, R. Type Locality of the Mutne Sandstone Member of the Jaworzynka Formation, Western Outer Carpathians, Poland. Ann. Soc. Geol. Pol. 2007, 77, 269-290.

50. Jurkiewicz, H. Otwornice z łupków czarnorzeckich wschodniej części jednostki śląskiej. Ann. Soc. Geol. Pol. 1960, $30,333-343$.

51. Tet'ák, F.; Cieszkowski, M.; Golonka, J.; Waśkowska, A.; Szczęch, M. The Ropianka Formation of the Bystrica Zone (Magura Nappe, Outer Carpathians: Proposal for a new reference section in northwestern Orava. Ann. Soc. Geol. Pol. 2017, 87, $259-274$. [CrossRef]

52. Bak, K. Deep-water agglutinated foraminiferal changes across the Cretaceous/Tertiary and Paleocene/Eocene transitions in the deep flysch environment; eastern part of Outer Carpathians (Bieszczady Mts., Poland). In Proceedings of the Six International Workshop on Agglutinated Foraminifera, Prague, Czech Republic, 6-7 September 2001; Bubík, M., Kamiński, M.A., Eds.; Grzybowski Foundation, Special Publication: Kraków, Poland, 2004; Volume 8, pp. 1-56.

53. Jednorowska, A. Zespoły otwornicowe w zewnętrznych strefach jednostki magurskiej Karpat i ich znaczenie stratygraficzne. Pr. Geol. Pol. Ak. Nauk O/Kraków Kom. Nauk Geol. 1968, 50, 1-89.

54. Waśkowska, A. Response of Early Eocene deep-water benthic foraminifera to volcanic ash falls in the Polish Outer Carpathians: Palaeocological implications. Palaeogeog. Palaeoclim. Palaeoecol. 2011, 305, 50-64. [CrossRef]

55. Waśkowska, A. The Early Eocene Saccamminoides carpathicus Assemblage in the Outer Flysch Carpathians. In Proceedings of the Eight International Workshop on Agglutinated Foraminifera, Cluj-Napoca, Romania, 7-13 September 2008; Kaminski, M.A., Filipescu, S., Eds.; Grzybowski Foundation, Special Publication: Kraków, Poland, 2011; Volume 16, pp. 331-341.

56. Waśkowska, A. The Eocene Hieroglyphic beds of the Silesian Nappe in the Western Polish Carpathians-their development and foraminiferal record. Geol. Quart. 2015, 59, 271-299. [CrossRef]

57. Pokorny, V. Microstratigraphie et biofaciès du flysch Carpatique de la Moravie Méridionale (Tchécoslovaquie). Rev. l'Inst. Fran. Pétr. Ann. Comb. Liq. 1960, 15, 1099-1141.

58. Hanzlíková, E. Carpathian Upper Cretaceous foraminifera of Moravia (Turonian-Maastrichtian); Vydal Ustredni Ustav Geologicky: Praha, Czechoslovakia, 1970; Volume 39, pp. 5-159.

59. Waśkowska, A.; Cieszkowski, M.; Golonka, J.; Kowal-Kasprzyk, J. Paleocene sedimentary record of ridge geodynamics in Outer Carpathian basins (Subsilesian Unit). Geol. Carpath. 2014, 65, 35-54. [CrossRef]

60. Cieszkowski, M.; Waskowska-Oliwa, A. Development and biostratigraphy of the Paleogene Gorzeń beds, Subsilesian Unit, Outer Carpathians, Poland. Geol. Carpath. 2002, 53, 57-58.

61. Waśkowska-Oliwa, A.; Leśniak, T. Biostratigraphy and palaeoecology of Early Palaeogene deep water foraminiferal assemblages from the Subsilesian Unit in the Żywiec Tectonic Window (Polish Outer Carpathians). Bull. Pol. Ac. Sc. Earth Sc. 2003, 51, 11-27.

62. Waśkowska-Oliwa, A. Foraminiferal palaeodepth indicators from the lower Palaeogene deposits of the Subsilesian Unit (Polish Outer Carpathians). Stud. Geol. Pol. 2005, 124, 297-324.

63. Valchev, B. On the stratigraphical distribution of small benthic foraminifera and the biostratigraphy of the Paleocene of the coastal part of east Stara Planina. Geol. Gfizi. 2004, 47, 43-49.

64. Golonka, J.; Waśkowska, A. Paleogene of the Magura Nappe adjacent to the Pieniny Klippen Belt between Szczawnica and Krościenko (Outer Carpathians, Poland). Geol. Geophis. Environ. 2014, 40, 359-376. [CrossRef]

65. Olszewska, B.; Odrzywolska-Bieńkowa, E.; Giel, M.D.; Pożaryska, K.; Szczechura, K. Rząd Foraminiferida Eichwald, 1830. In Budowa geologiczna Polski, Atlas skamieniałości przewodnich i charakterystycznych, Kenozoik, Trzeciorzęd, Paleogen, T 3, cz. 3a; Limanowska, L., Piwocki, M., Eds.; Wydawnictwa Geologiczne: Warszawa, Poland, 1996; pp. 45-215.

66. Huss, F. Otwornice aglutynujące serii podśląskiej roponaśnej jednostki Węglówki, polskie Karpaty fliszowe. Prace Geol. PAN 1966, $34,7-71$.

67. Jednorowska, A. Small Foraminifera assemblages in the Paleocene of the Polish Western Carpathians. Stud. Geol. Pol. 1975, 47, 3-103.

68. Liszkowa, J.; Morgiel, J. Mikrofauna typu frydeckiego w polskich Karpatach Zewnętrznych. Biul. Inst. Geol. 1981, 331, 83-102.

69. Kaminski, M.A.; Alegret, L.; Santoso, S.H.; Waskowska, A. The Paleocene of IODP Site U1511, Tasman Sea: A lagerstatten deposit for deep-water agglutinated foraminifera. Micropaleontology 2021, 4, 41-364. [CrossRef]

70. Berggren, W.A.; Kent, D.V.; Swisher, C.C.; Aubry, M.P. A revised Cenozoic geochronology and chronostratigraphy. A revised Cenozoic geochronology and chronostratigraphy. Geochr. Time Scales Glob. Stratig. Corr. 1995, 54, 129-212.

71. Waśkowska-Oliwa, A. Przegląd geologiczny. Biostratygrafia otwornicowa tufitów okna tektonicznego Wiśniowej. Przeg. Geol. 2003, 51, 261-262.

72. Olszewska, B.; Smagowicz, M. Porównanie podziałów biostratygraficznych górnej kredy i paleogenu jednostki dukielskiej na podstawie otwornic planktonicznych i nannoplanktonu wapiennego. Przeg. Geol. 1977, 25, 359-363. 
73. Bakk, K.; Bąk, M.; Geroch, S.; Manecki, M. Biostratigraphy and paleoenvironmental analysis of benthic foraminifera and radiolarians in Paleogene variegated shales in the Skole unit, Polish Flysch Carpathians. Ann. Soc. Geol. Pol. 1997, 67, 135-154.

74. Morgiel, J.; Szymakowska, F. Stratygrafia paleocenu i eocenu jednostki skolskiej. Biul. Inst. Geol. 1978, 310, 39-71.

75. Arreguín-Rodríguez, G.J.; Alegret, L.; Ortiz, S. Glomospira acme during the Paleocene-Eocene Thermal Maximum: Response to $\mathrm{CaCO}_{3}$ dissolution or to ecological forces? J. Foraminifer. Res. 2013, 43, 40-54. [CrossRef]

76. Arreguín-Rodríguez, G.J.; Alegret, L.; Sepúlveda, J.; Newman, S.; Summons, R.E. Enhanced terrestrial input supporting the Glomospira acme across the Paleocene-Eocene boundary in Southern Spain. Micropaleontology 2014, 60, 43-51.

77. Galeotti, S.; Kaminski, M.A.; Coccioni, R.; Speijer, R. High resolution Deep Water Agglutinated foraminiferal record across the Paleocene/Eocene transition in the Contessa Road Section (central Italy). In Proceedings of the Sixth International Workshop on Agglutinated Foraminifera, Prague, Czech Republic, 6-7 September 2001; Bubik, M., Kaminski, M.A., Eds.; Grzybowski Foundation, Special Publication: Kraków, Poland, 2011; Volume 8, pp. 83-103.

78. Waśkowska, A.; Cieszkowski, M.; Bębenek, S. Trochammina semi-specific assemblages from the Upper Paleocene of the Silesian Nappe, Polish Outer Carpathians. In Proceedings of the Ninth International Workshop on Agglutinated Foraminifera, Zaragoza, Spain, 3-7 September 2012; Kaminski, M.A., Alegret, L., Eds.; Grzybowski Foundation, Special Publication: Kraków, Poland, 2017; Volume 22, pp. 239-249.

79. Waśkowska, A. Small-sized Trochammina assemblages in deep-water Eocene flysch deposits (Outer Carpathians, Poland) and their palaeoecological implications. J. Micropal. 2015, 34, 1-19. [CrossRef]

80. Nagy, J.; Jargvoll, D.; Dypvik, H.; Jochmann, M.; Riber, L. Environmental changes during the Paleocene-Eocene Thermal Maximum in Spitsbergen as reflected by benthic foraminifera. Polar Res. 2013, 32. [CrossRef]

81. Oszczypko, N. Budowa geologiczna północnych stoków Beskidu Sądeckiego między Dunajcem a Popradem (płaszczowina magurska). Ann. Soc. Geol. Pol. 1979, 49, 293-325.

82. Waśkowska, A. The Eocene Hieroglyphic beds and Green shales in the Rożnów Lake area (Silesian Nappe, Outer Carpathians)— facies development and biostratigraphy. Geol. Geoph. Environ. 2014, 40, 5-26. [CrossRef]

83. Waskowska, A.; Cieszkowski, M. Utwory eoceńskie strefy Siar płaszczowiny magurskiej na terenie rezerwatu krajobrazowego Zamczysko nad Raba (polskie Karpaty zewnętrzne). Chroń. Przyr. Ojcz. 2015, 71, 96-107.

84. Waśkowska, A. Stratigraphy of the Hieroglyphic Beds with "Black Eocene" facies in the Silesian Nappe (Outer Flysch Carpathians, Poland). Ann. Soc. Geol. Pol. 2015, 85, 321-343. [CrossRef]

85. Bindiu, R.; Filipescu, S. Foraminiferal biostratigraphy and paleoenvironments of the middle Eocene deposits from the northern part of the Tarcău Nappe (Eastern Carpathians, Romania). Stud. UBB Geol. 2014, 59, 45-59. [CrossRef]

86. Bindiu, R.; Filipescu, S.; Balc, R.; Cocis, L.; Gligor, D. The middle/late Eocene transition in the Eastern Carpathians (Romania) based on foraminifera and calcareous nannofossil assemblages. Geol. Quart. 2016, 60, 38-55.

87. Săndulescu, M. Geotectonics of Romania; Editura Tehnică: Bucureşti, Romania, 1984; pp. 1-334.

88. Săndulescu, M.; Micu, M.; Bratu, E. Stratigraphy of the Eocene Flysch formations of the East Carpathians. In The Eocene from the Transylvanian Basin, Romania. Geological Formations of Transylvania; Petrescu, I., Ghergari, L., Mészáros, N., Nicorici, E., Eds.; Babes-Bolyai University: Cluj-Napoca, Romania, 1987; pp. 159-164.

89. Kaminski, M.A. The utility of Deep-Water Agglutinated Foraminiferal acmes for correlating Eocene to Oligocene abyssal sediments in the North Atlantic and Western Tethys. Stud. Geol. Pol. 2005, 124, 325-340.

90. Grzybowski, J. Otwornice czerwonych iłów z Wadowic. Rozpr. Wydz. Mat. Przyr. Ak. Umiej. 1896, 30, $261-308$.

91. Kaminski, M.A.; Silye, L.; Kender, S. Miocene deep-water agglutinated foraminifera from ODP Hole 909c: Implications for the paleoceanography of the Fram Strait Area, Greenland Sea. Micropaleontology 2005, 51, 373-403. [CrossRef]

92. Cieszkowski, M.; Waśkowska, A.; Kaminski, M. Deep water agglutinated foraminifera in Paleogene hemipelagic sediments of the Magura Basin in the Sucha Beskidzka area-Variegated shales of the Łabowa Shales Formation. In Integrating Microfossil Records from the Oceans and Epicontinental Seas; Bak, M., Kaminski, M.A., Waśkowska, A., Eds.; Grzybowski Foundation, Special Publication: Kraków, Poland, 2011; Volume 17, pp. 3-63.

93. Waśkowska, A.; Hnylko, S.; Kaminski, M.A.; Bakayewa, S. Grzybowski's Lviv Collection of Carpathian Foraminifera; Grzybowski Foundation: Kraków, Poland, 2020; Volume 25, pp. 1-169.

94. Hnylko, O.; Hnylko, S. Geological environments forming the Eocene black-shale formation of the Silesian Nappe (Ukrainian Carpathians). Geodynamics 2019, 26, 60-75. [CrossRef]

95. Waśkowska-Oliwa, A. Haplophragmoides nauticus Kender, Kaminski \& Jones in the Eocene of the Flysch Carpathians. In Proceedings of the Eighth International Workshop on Agglutinated Foraminifera, Cluj-Napoca, Romania, 7-13 September 2008; Filipescu, S., Kaminski, M.A., Eds.; Grzybowski Foundation, Special Publication: Kraków, Poland, 2008; Volume 14, pp. 63-64.

96. Kender, S.; Kaminski, M.A.; Jones, R.W. Four new species of deep-water agglutinated foraminifera from the Oligocene-Miocene of the Congo Fan (offshore Angola). Micropaleontology 2007, 52, 465-470. [CrossRef]

97. Bubik, M. Nove a malo zname aglutinovane foraminifery z paleogenu jizni Moravy. Zpravy Geol. Vyzk. 2009, 82-84. Available online: https:/ / www.semanticscholar.org/paper/Nov\%C3\%A9-a-m\%C3\%A1lo-zn\%C3\%A1m\%C3\%A9-aglutinovan\% C3\%A9-foraminifery-z-ji\%C5\%BEn\%C3\%AD-Bubi\%CC\%81k/f5a61358c742c02a0c62d8ccb2ad885c87e8acbb (accessed on 31 August 2021). 
98. Bubik, M. A tribute to Prof. Anton Rzehak and the first micropaleontological analysis in the Magura Flysch. In Proceedings of the Seventh International Workshop on Agglutinated Foraminifera, Urbino, Italy, 2-8 October 2005; Kaminski, M.A., Cocioni, R., Eds.; Grzybowski Foundation, Special Publication: Kraków, Poland, 2008; Volume 13, pp. 1-12.

99. Golonka, J.; Waśkowska, A. The Beloveža Formation of the Rača Unit in the Beskid Niski Mts. (Magura Nappe, Polish Flysch Carpathians) and adjacent parts of Slovakia and their equivalents in the western part of the Magura Nappe; remarks on the Beloveža Formation-Hieroglyphic Beds. Geol. Quart. 2012, 56, 821-832. [CrossRef]

100. Waśkowska, A. Bulbobaculites gorlicensis n. sp.-A new agglutinated foraminifera from Eocene of flysch Carpathians. Micropaleontology 2014, 60, 465-473.

101. Cieszkowski, M.; Leśniak, T.; Środoń, J.; Waśkowska-Oliwa, A. Bentonitized tuffites in the Lower Eocene deposits of the Subsilesian Unit (Wester Outer Carpathians, Poland). Ann. Soc. Geol. Pol. 2006, 76, 197-214.

102. Morgiel, J. Mikrofauna iłów babickich. Biul. Inst. Geol. 1959, 131, 7-48.

103. Bindiu-Haitonic, R.; Filipescu, S.; Aroldi, C.; Oltean, G.; Chira, C.M. Eocene Deep-Water Agglutinated Foraminifera from the Eastern Carpathians (Romania): Paleoenvironments and Biostratigraphical Remarks. Micropaleontology 2019, 65, 47-61.

104. Kuhnt, W.; Kaminski, M.A. The response of benthic foraminifera to the K/T boundary event-a review. Bull. Centres Rech. Explor. Mem. 1996, 16, 433-442.

105. Nagy, J.; Kaminski, M.A.; Gradstein, F.M.; Johnson, K. Quantitative foraminiferal and palynomorph biostratigraphy of the Paleogene in the southwestern Barents Sea. In Proceedings of the Sixth International Workshop on Agglutinated Foraminifera, Prague, Czech Republic, 6-7 September 2001; Bubík, M., Kaminski, M.A., Eds.; Grzybowski Foundation, Special Publication: Kraków, Poland, 2004; Volume 8, pp. 359-379.

106. Nagy, J.; Kaminski, M.A.; Johnsen, K.; Mitlehner, A. Benthic foraminiferal and dinoflagellate cyst stratigraphy and paleoenvironments of the Palaeogene Torsk Formation: A reference section for the western Barents Sea. In Micropalaeontology and Paleoceanography of the northern North Atlantic; Hass, C., Kaminski, M.A., Eds.; Grzybowski Foundation, Special Publication: Kraków, Poland, 1997; Volume 5, pp. 15-38.

107. Waśkowska, A.; Kaminski, M.A. “Ammodiscus" latus Grzybowski, 1898: Its taxonomy, variability, and affinity to the genus Trochamminoides Cushman, 1910. In Proceedings of the Eight International Workshop on Agglutinated Foraminifera; Kaminski, M.A., Filipescu, S., Eds.; Grzybowski Foundation, Special Publication: Kraków, Poland, 2017; Volume 22, pp. $229-238$.

108. Olszewska, B.; Szydło, A. Environmental stress in the northern Tethys during the Paleogene: A review of foraminiferal and geochemical records from the Polish Outer Carpathians. Geol. Quar. 2017, 61, 682-696. [CrossRef]

109. Olszewska, B. Oniektórych zespołach małych otwornic serii okiennej z Sopotni Małej, Mszany Dolnej, Szczawy i Klęczan. Biul. Inst. Geol. 1981, 21, 141-163.

110. Jednorowska, A. Some assemblages of planktonic foraminifera from the Eocene of the Magura Series (Polish Flysch Carpathians). Rocz. Pol. Tow. Geol. 1969, 39, 277-294.

111. Blaicher, J. Poziom wapiennej mikrofauny w górnym eocenie serii magurskiej. Zone with calcareous microfauna in the Upper Eocene of the Magura Series (Flysch Carptahinas). Biul. Inst. Geol. 1961, 166, 5-59.

112. Golonka, J.; Waśkowska, A. The Beloveža Formation of the Rača Unit, Magura Nappe, in the Beskid Wysoki Mts (Polish Flysch Carpathians) north of Babia Góra Mountain-monospecific assemblages with Praesphaerammina subgaleata (Vašiček). In Integrating Microfossil Records from the Oceans and Epicontinental Seas; Bakk, M., Kaminski, M.A., Waśkowska, A., Eds.; Grzybowski Foundation, Special Publication: Kraków, Poland, 2011; Volume 17, pp. 27-35.

113. Jednorowska, A.; Wẹcławik, S. Startygrfia mikropaleontologiczna osadów kredy górnej i paleogenu warstw jednostki magurskiej z rejonu Wysowej (Beskid Niski). Spraw. Pos. PAN Odd. Kraków 1969, 12, 263-266.

114. Książkiewicz, M. Detailed Geological Map of Poland, 1:50,000, Zawoja Sheet_Explanations; Instytut Geologiczny: Warszawa, Poland, 1971; pp. 1-154.

115. Książkiewicz, M. Detailed Geological Map of Poland, 1:50,000, Sucha Beskidzka Sheet_Explanations; Instytut Geologiczny: Warszawa, Poland, 1974; pp. 1-83.

116. Vašíček, M. Poznamky k mikrobiostratigrafii magurskeho flyse na Morave. Vest. Stat. Geol. Ust. Ceskosl. Rep. 1947, $22,235-256$.

117. Wẹcławik, S. Budowa geologiczna płaszczowiny magurskiej między Uściem Gorlickim a Tyliczem. The geological structure of the Magura Nappe between Uście Gorlickie and Tylicz. Pr. Geol. Kom. Nauk Geol. PAN Odd. Kraków 1969, 59, 1-101.

118. Săndulescu, M.; Bratu, E. Nouvelles donnees pour la correlation des Formationa Paleogenes des unites allochtonnes de la Zone du Flysch Transcarpathique (Maramures). Dari Seama Instit. Geol. Geof. 1981, 68, 119-135.

119. Gradstein, F.; Waśkowska, A.; Glinskikh, L. The first 40 million years of planktonic foraminifera. Geoscience 2021, 11, 5. [CrossRef] 